\title{
A RESPONSABILIDADE PÚBLICA NO DIREITO BRASILEIRO E NO DIREITO ESTRANGEIRO
}

\author{
Jõ̃o ANTUNES dOS SANTOS NETO*
}

\begin{abstract}
1. Generalidades. 2. Pressupostos da responsabilidade extracontratual do Estado. 2.1. Responsabilidade extracontratual do Estado - evolução histórica. 2.1.1. Teoria da irresponsabilidade. 2.1.2. Teorias civilistas - a teoria da culpa (primeiro momento). 2.1.3. Teorias Civilistas - a teoria da culpa (segundo momento). 2.1.4. Teorias Publicistas. 3.1.4.1. Teoria da culpa do serviço. 3.1.4.2. Teoria do risco integral. 4. A responsabilidade extracontratual do Estado no direito brasileiro. 5. Causas excludentes da responsabilidade extracontratual do Estado. 6. Fundamentos da responsabilidade extracontratual do Estado. 6.1. Responsabilidade extracontratual do Estado por atos legislativos. 6.2. Responsabilidade extracontratual do Estado por atos judiciais e jurisdicionais. 7. A responsabilidade extracontratual do Estado no direito estrangeiro. 7.1. O direito francês. 7.2. O direito italiano. 7.3. $O$ direito espanhol. 7.4. $O$ direito argentino. 8. Considerações finais. Bibliografia.
\end{abstract}

\section{Generalidades}

A divisão do direito público e privado já era conhecida dos romanos, desde seus primórdios. Atribui-se a Ulpiano, grande jurisconsulto de Roma, interessante pro-

* O autor é Juiz de Direito no Estado de São Paulo. Professor Titular da Cadeira de Direito Administrativo da Faculdade de Direito de São Bernardo do Campo e Professor do Curso de Pós-Graduação em Direito Público da Escola Paulista da Magistratura. É mestre e doutorando em Direito do Estado (Direito Administrativo) pela Universidade de São Paulo.

R. Dir. Adm.,

Rio de Janeiro, 239: 255-298,

Jan./Mar. 2005 
posição, posteriormente compilada por Justiniano', que pretendeu sistematizar o direito romano por meio de um trabalho de codificação $o^{2}$, e que consistia no seguinte - Hujus studii duae sunt positiones: publicum et privatum. Publicum jus est quod ad sttatum rei romanae spectat; privatum quod singulorum utilitatem: sunt enim quaedam publice utilia, quaedam privatum (Digesto, $I, 1,1,2)$ - "Duas são as proposições concernentes ao estudo do direito; uma relativa ao estudo do direito público, ou seja, o que diz respeito ao modo de ser do Estado romano; outra atinente ao direito privado, ou seja, o que trata dos interesses particulares. Com efeito, algumas coisas são úteis publicamente, outras, privadamente" ${ }^{3}$.

Esta colocação, a despeito de anciã, teria trazido "as maiores polêmicas" no campo do direito, "podendo-se hoje afirmar que ela encerra mais dúvidas do que soluções", eis que se a definição de Ulpiano foi suficiente ao direito romano, hodiernamente é "insuficiente para explicar as sutilizas que caracterizam o direito comum e o direito público" contemporâneos, até porque em Roma era mais acentuada a divisão ente indivíduo e Estado 4 .

Como conseqüência do "esfacelamento do poder", na Idade Média referida divisão entre direito público e privado teria perdido sua clareza, eis que na época medieval, "confundiu-se soberania e propriedade" - esta assumiu conotação política, posto que aquele que detinha "de direito o domínio, exercia poderes típicos de Estado sobre o servo ou vassalo, que era obrigado a cultivar a terra pagando pedados tributos ao proprietário". Com a Revolução Francesa e com o consequiente ressurgimento de um poder central com "a unificação do conceito de soberania", a divisão entre direito público e privado volta a aparecer, "embora sem perfeita correspondência no que diz respeito a seu conteúdo. Para alguns, só depois de promulgado o Código Civil Francês de 1.804 é que tal distinção foi considerada para o direito" 5 .

1 Justiniano o fez nas Institutas (I, 1,4). Estas integraram o que Dionísio Godofredo chamou séculos mais tarde (1538) de Corpus Juris Civilis, que por sua vez compilava quatro livros: que compilava quatro livros - Pandectas (Digesto), Codex, Institutas e Nouellae (Novelas). Justiniano ordenou o direito ao reunir os textos de lei do Período Clássico e as Constituições Imperiais anteriores do direito romano, agregando a eles, ainda, material didático de enorme contribuição para os estudiosos, como também as Constituições posteriormente editadas por ele próprio, no Império Romano do Oriente. Sobre o assunto, consultar Moreira Alves, José Carlos. Direito Romano. Rio de Janeiro, Forense, 2001, p. 48.

2 Não obstante, de se ter que referido intento de Justiniano não passou de um verdadeiro arremedo de codificação que, no entanto. não pode ser tido por trabalho sistemático ou mesmo ser chamado de sistematização em razão de dois dados significativos: a palavra sistema só foi introduzida no pensamento jurídico no século XVI e se tornou um termo técnico somente no século XVIII. Mais que isto, "o sistema do direito romano é uma criação do século XIX". Sobre o assunto, consulte-se FERRAZ JÚNIOR, Tércio Sampaio. Introdução ao Estudo do Direito - Técnica, Decisão, Dominação, São Paulo, Atlas, 2003, p. 178 e seguintes.

3 DI PIETRO. Maria Sylvia Zanella. Do Direito Privado na Administração Pública. São Paulo, Atlas, 1989 , p. 15.

4 DI PIETRO, Maria Sylvia Zanella. Do Direito Privado na Administração Pública. Op. cit., p. 16.

5 DI PIETRO, Maria Sylvia Zanella. Do Direito Privado na Administração Pública. Op. cit., p. 16. 
O direito público passou então a se desenvolver, fenômeno que se incrementou a partir do momento em que o "Estado foi se afastando de sua posição passiva, própria do liberalismo, e assumindo inúmeras funções no campo social". Decorrência desta situação foi o surgimento de novos e específicos institutos de direito público, que ampliou "consideravelmente seu conteúdo e alcance" ". Dentre estes institutos destaca-se o da responsabilidade extracontratual do Estado.

A teoria da responsabilidade civil extracontratual estruturou-se no direito romano, a partir do princípio damnum iniuria datum, cuja elaboração, apontam alguns estudiosos, lançou bases nas disposições de uma lei, denominada Lex Aquilia, provavelmente editada no século III a.C. ${ }^{7}$ Originariamente, as disposições desta lei só se aplicavam ao dano causado por ato positivo e consistente em estrago físico e material da coisa corpórea, além de ser exigência da Lex Aquilia que a "danificação

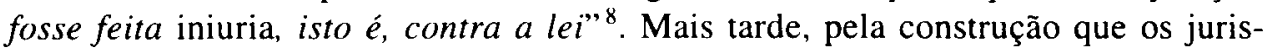
consultos deram ao instituto, a palavra iniuria passou a indicar, também, a culpabilidade do autor do dano e não somente o ilícito, o contrário à lei - a exigência era a de que o dano fosse causado dolosa ou culposamente por um agente, sendo a ele imputável responsabilidade pela reparação daquelas lesões, ainda que oriundas da mais leve negligência (in Lege Aquilia et levissima culpa venit).

Posteriormente, os ditames do diploma em epígrafe se estenderam de modo a contemplar os danos causados por omissão ou verificados sem o estrago físico e material da coisa - o valor do dano, que se calculava pela quantificação objetiva do valor da coisa, passou a incluir todo o interesse do proprietário relativamente a ela; além do dano efetivo e material (damnum emergens), contemplava-se, da mesma forma, a perda do lucro (lucrum cessans) sofrida por aquele em razão do ato ilícito do ofensor?.

A iniuria, ofensa ilícita causada à pessoa de outrem, no direito romano clássico, podia ser de qualquer espécie - física ou moral —, permitindo ao ofendido reclamar indenização por meio de uma ação denominada actio iniuriarium, que se dirigia tanto ao ofensor quanto às demais pessoas que concorreram ao delito, de forma ativa ou passiva.

Entretanto, mesmo antes da assunção da chamada responsabilidade aquiliana, assim denominada, obviamente, a partir do édito da referida Lex Aquilia, relatos se encontram de indicação do reconhecimento da existência da consagração do instituto epigrafado em momentos históricos ainda mais antigos. Assim é que Limongi Fran$c^{10}{ }^{10}$, ao se referir ao "pai de todos os códigos", a saber, o Código de Hamurabi,

6 DI PIETRO, Maria Sylvia Zanella. Do Direito Privado na Administraçāo Pública. Op. cit., pp. 16-17.

7 MARKY, Tomas. Curso Elementar de Direito Romano. São Paulo, Saraiva, 1995, p. 136.

8 MARKY, Tomas. Op. cit., p. 136.

9 MARKY, Tomas. Op. cit., p. 136.

10 LIMONGI FRANÇA, R.. Responsabilidade Aquiliana e Suas Raizes. In, Responsabilidade Civil - Doutrina e Jurisprudência. CAHALI, Yussef Said (org.). São Paulo, Saraiva, 1988, p. 244 e seguintes. 
datado de cerca de dois mil e duzentos anos a. C., consagrador da denominada pena de taliāo (olho por olho, dente por dente), aponta para um de seus dispositivos (parágrafo 219) que parece ordenar preceito "semelhante ao da responsabilidade civil do direito moderno". Referida disposição prescrevia que "se um médico faz uma incisão difícil com uma faca de bronze no escravo de um muskénum e causou a sua morte. ele deverá restituir um escravo como o escravo morto".

Além dos babilonios - que escreveram o código de Hamurabi - os indianos, ainda na antiguidade, também se preocupavam com o assunto. A despeito de trazer disposições "esparsas e fragmentárias", encontra-se no livro VIII, parágrafo 224. do Código de Manu - cuja compilação, transmitidas pelos antigos sábios (Rishis), dataria do século XIII a. C. - previsão de indenização por "defeito oculto da noiva" (nesse dispositivo do livro VIII do código de Manu, cabia impor pesada multa àquele que "desse em casamento uma donzela com defeitos"); no parágrafo 240 do referido diploma, vislumbra-se a indenização "por danos causados por animais", assim como, também, em seu corpo, havia preceito assim entabulado: na condenação de um inocente, impunha-se aos juízes, na revisão do processo, "multa pecuniária de mil panas" "I.

Sobre o texto do Código de Manu - é importante colacionar - conforme atenta Limongi França, que na tradução desenvolvida por Deslongchamps, se encontra uma locução inserta no 232 de seu capitulado que parece ser o embrião do que hodiernamente conhecemos por negligência. $\dot{\mathrm{E}}$ da transcrição literal da referida versão do dispositivo em comento e que parece constituir a idéia basilar daquele importante elemento da culpa moderna que, "quando um animal vem a perder-se, é morto por répteis, ou por cães, ou cai num precipício, e isto por negligência do guardião, este é obrigado a pagar um outro igual".

Também os hebraicos consagraram, em seu Pentateuco, mais especificamente no livro denominado Levítico $(24,19-20)$, a "velha e bárbara" pena de talião, posto que se regiam pela regra que antevia que "o que ferir qualquer de seus compatriotas, assim como fez, assim se fará a ele; quebradura por quebradura, olho por olho, dente por dente; qual for o mal que tiver feito, tal será o que há de sofrer".

Do mesmo modo do que ocorre com os textos antigos contemporâneos da ordenação hebraica e que já foram objeto de debate anterior, Limongi França encontra no ordenamento judaico similitude da responsabilidade civil conforme consagrada em nossos dias, ao cotejar os fundamentos universais que hoje regem a responsabilidade civil, com a prescrição do v. 18 do ancião diploma em testilha, que assim trazia prescrito: "o que ferir ou matar um animal restituirá outro em seu lugar; isto é, animal por animal" 12.

Mesmo na Grécia antiga, que ao contrário de Roma, se notabilizou pelo desenvolvimento da filosofia e não pelo incremento de um ordenamento construído pelo direito, traço marcante da segunda civilização citada, já se encontrava, ainda que na literatura - que por sua vez remetia à mitologia — exemplo de preocupação com

11 Esta disposição indica claramente a preocupação com o ressarcimento de dano moral.

12 Também o v. 21 é citado pelo autor: "o que matar um jumento, restituirá outro". 
o problema da responsabilidade. Isto, ao menos, é o que se pode extrair de excerto da clássica Odisséia, de Homero. quando em uma de suas passagens, o protagonista, surpreendendo a esposa Afrodite em flagrante adultério, aponta para o favorecimento do marido coxo com o benefício de pesada multa, isto, no julgamento feito pelos deuses.

No direito romano anterior, a Lei das XII Tábuas parece ter evoluído os conceitos primitivos do código de Hamurabi, sem embargo, outrossim, do fato daquele diploma não abandonar alguns aspectos bárbaros do pai de todos os códigos, como, por exemplo, a própria pena de taliāo, aplicável, à oportunidade, a quem ferisse a outrem (Lei $\left.{ }^{\circ} 11\right)^{13}$. Da mesma forma, a Tábua Sétima, cujo título, De Delictis, expressava seu objeto, prescrevia, dentre outras, disposições relevantes naquele sentido: "I. se um quadrúpede causar qualquer dano, que o seu proprietário indenize o valor desse dano ou abandone o animal ao prejudicado; 2. se alguém causa um dano premeditadamente, que o repare; 9. aquele que causar dano leve indenize vinte e cinco asses".

Além da Lei das XII Tábuas, também são referências legislativas do direito romano anterior à Lex Aquilia, a lex Pesolania, lembrada por Othon Sidou como sendo "de data incerta, co-formadora dos princípios da responsabilidade noxal, atribuída ao paterfamílias pelos danos causados por pessoas à sua potestade" 14 .

Estes diplomas legais, entretanto, foram revogados com a edição da Lex Aquilia, assim denominada em razão daquele a quem Ulpiano atribuiu sua autoria: o Tribuno Aquilius - cum eam Aquilius tribunis plebis a plebe rogaverit ${ }^{15}$, não obstante referido texto normativo ter sido submetido a plebiscito. Justiniano, nas Institutas $(1,2,4)$, por seu turno, explicita que em Roma, "o plebiscito é o que a plebe, por proposta de um magistrado plebeu, ou seja, o tribuno, constituía - quod plebis plebeio magistratu interrogante, veluti tribuno, constituebat"; o plebiscito, após a edição da Lex Hortensia, editada em 287 a.C., passa a obrigar aos patrícios, equiparando-se à lex publica ${ }^{16}$.

A responsabilidade aquiliana foi recepcionada por leis posteriores, que a desenvolveram. Isto ocorreu com a edição do código Justinianeu (Livro III, Título XXXV) e do Digesto (Livro IX, Título II). Ao se observar a divisão do Império Romano, por obra do imperador Theodosio, observou-se, também, que, enquanto na Roma do Oriente (Bizâncio) a coletânea justinianéia desenvolveu-se sem rupturas, na Roma do Ocidente, com o advento das invasões bárbaras e mouras, o instituto da responsabilidade civil organizou-se pela seara da fragmentação. Tanto é que o Código Visigótico de 671 d. C., vigorou em Portugal até 1446, quando foi substituído pelo texto das Ordenações Afonsinas, e na Espanha, até 1889, data da entrada em vigor do Código Civil ${ }^{17}$.

13 Si membrum rupsit, ni cum eo placit, talio est.

14 SIDOU, Othon. Apud, LIMONGI FRANÇA, R.. Op. cit., p. 246.

15 LIMONGI FRANÇA, R.. Op. cit., p. 247.

16 LIMONGI FRANÇA, R. Op. cit., p. 248.

17 LIMONGI FRANÇA, R.. Op. cit., pp. 257-258. 
A evolução da matéria só foi sentida, na Idade Média, a partir do fenômeno da Glosa e da Pós-Glosa, cuja generalidade da construção prepararam terreno à modernização do direito civil, bem como serviu de sustentáculo à sua codificação dos séculos XIX e XX; já nessa era, constituiu obra paradigmática do período o Código de Napoleão ${ }^{18}$, referência para a edição de diversos códigos similares nos mais variados países, dente eles, Japão, China, Portugal e Brasil.

\section{Pressupostos da responsabilidade extracontratual do Estado}

As bases da responsabilidade civil, construídas pelo chamado direito comum, na conformidade com o que restou expendido, integram, dentre outras instituições, o que se convencionou chamar de teoria geral do direito. Seus institutos, justamente por serem gerais, não pertencem, exclusivamente, ao direito civil, senão a toda ciência jurídica, razão de que, são universais. Assim, pois, não é diferente quando o assunto é tratado pelo direito público; este, entretanto, face de seus traços e conotações típicos, derroga e exorbita as regras comuns construídas sobre aqueles alicerces privatísticos, de modo a adaptá-las à sua realidade, criando, dessa forma, uma concepção publicista da responsabilidade.

Por estes motivos é que a evolução do instituto da responsabilidade do Estado, observado de maneira autônoma, guardou características próprias e diversas daquelas já apresentadas, a despeito de se valer de suas bases e conceitos no processo evolutivo observado em razão da matéria.

\subsection{Responsabilidade extracontratual do Estado - evolução histórica}

Já tivemos a oportunidade de afirmar que "o Estado, cujo conceito cambiante modifica-se face da evolução não só do instituto que representa, mas especialmente pelos incrementos observados na sociedade transcendente, recebeu através dos tempos, como não poderia deixar de ser e mesmo em razão desta esta vicissitude, tratamento jurídico diversificado, máxime no que tange aos estágios de evolução do reconhecimento da responsabilidade civil que decorria de seus atos" 19 .

Quanto à matéria em debate, ainda é relevante colacionar que o fenômeno descrito restou observado tanto nos Estados que se filiaram ao sistema de bases romano-germânicas quanto naqueles que adotaram o common law como arcabouço de suas respectivas ordens jurídicas. Neste diapasão, a doutrina aponta que a evolução dos conceitos da responsabilidade extracontratual do Estado dividiu-se em quatro períodos distintos, "identificados pelos regimes políticos diferenciados" 20 que se caracterizavam cada um deles, pelos diferentes momentos históricos em que ascen-

18 LIMONGI FRANÇA, R., Op. cit., p. 259.

19 SANTOS NETO, João Antunes dos. Responsabilidade do Estado por Atos Judiciais e Jurisdicionais. BDA - Boletim de Direito Administrativo. São Paulo, NDJ, 2002, ano XVIII, $n^{\circ} 1$, pp. 23-29.

20 SANTOS NETO, João Antunes dos. Op. cit., pp. 23-29. 
deram a informar o sistema do direito público. Assim é que, da irresponsabilidade absoluta do Estado, seguiu-se para a adoção de soluções civilistas de responsabilidade lastreadas na idéia de culpa - no primeiro momento a responsabilidade só era oponível aos servidores; no segundo, ainda sob o viés da culpabilidade, admitiu-se a responsabilização do Estado em razão do funcionamento dos serviços públicos. $O$ último dos períodos notados na síntese evolutiva da responsabilidade extracontratual do Estado é frequientemente citado pela doutrina como aquele que reconheceu a acumulação de responsabilidades ${ }^{21}$.

Destarte e em razão destas vicissitudes, a doutrina, fortemente auxiliada pela jurisprudência, solidificada nos mais diversos países que formam a comunidade internacional de nações ${ }^{22}$, construiu algumas teorias para identificar o progresso do instituto da responsabilidade extracontratual do Estado através dos tempos. Estas teorias são identificadas pela comunidade científica como teoria da irresponsabilidade, teorias civilistas e teorias publicistas, informadoras do conceito da responsabilidade patrimonial não contratual do Estado.

\subsubsection{Teoria da irresponsabilidade}

Esta teoria foi adotada na época dos Estados absolutistas e "repousava na idéia de soberania" 23. A soberania do Estado, poder incontrastável, impedia fosse reconhecida sua responsabilidade perante um indivíduo - O Estado e o monarca não erram; o Estado atua para atender o interesse de todos e não pode ser responsabilizado por isso ${ }^{24}$.

Enterría e Fernández nos esclarecem que a afirmação de uma responsabilidade patrimonial do soberano por danos resultantes da atuação de seus agentes, "pugnava frontalmente com uma tradição multissecular, que através de uma combinação da potestas imperial romana e da concepção teocêntrica do poder do monarca, característica do mundo medieval, encontrou sua concepção clássica no princípio formulado pelos juristas ingleses que, entretanto, era comum a todo o Ocidente, segundo $o$ qual the king can do no wrong (o rei não pratica ilícitos)" 25 .

Vale, entretanto, conferir, que a locução the king, na forma como afirmada no princípio epigrafado, não corresponde "tão somente ao rei" ${ }^{26}$, mas a todos os servants of the crown (funcionários e altos funcionários da coroa).

21 A responsabilidade teria lugar, então, segundo a natureza da falta, seja pessoal ou de serviço, que causasse danos a terceiros; fixou-se, desta maneira, a chamada teoria da acumulaçāo das responsabilidades, abrindo ao prejudicado a oportunidade de agir contra o funcionário ou contra a Administração, segundo sua opção própria.

22 A despeito de o fenômeno ser mais marcante na França, a partir dos julgados do Conselho de Estado.

23 DI PIETRO, Maria Sylvia Zanella. Direito Administrativo. São Paulo, Atlas, 2003, p. 525.

24 MEDAUAR, Odete. Direito Administrativo Moderno. São Paulo, Revista dos Tribunais, 2003, p. 393.

25 ENTERRÍA, Eduardo García de; FERNÁNDEZ, Tomás-Ramón. Curso de Derecho Administrativo. Madrid, Civitas, 2.000, t. II, p. 357.

26 DIAS, José de Aguiar. Da Responsabilidade Civil. Rio de Janeiro, Forense, 1987, v. II, p. 651, nota 970 . 
Sob o viés estabelecido pela teoria em comento, o Estado, ao dispor de poder incontrastável perante o súdito, como também em razão de exercer a tutela do direito. não poderia agir de modo a violar a ordem por ele (direito) estabelecida; "qualquer responsabilidade atribuída ao Estado significaria colocá-lo no mesmo nivel que o súdito, em desrespeito à sua soberania" ${ }^{27}$.

Corolário do princípio do the king can do no wrong é o do le roi ne peut mal faire, que juntamente com o brocardo latino consubstanciado na expressão quod principi placuit habet legis vigorem ${ }^{28}$, se fixaram em sustentáculo à impossibilidade de responsabilização do Estado pelos danos que de sua dinâmica pudessem ser observados.

Esta teoria da irresponsabilidade, entretanto, apresentava enorme contradição: o Estado, como pessoa jurídica que é. também é sujeito de direitos e obrigações; mais que isto, se ao Estado se outorga a tutela do direito, nâo se poderia permitir que, nesta condição, deixasse que a ordem jurídica fosse maculada quando ele próprio, por ação ou omissão, causasse danos a terceiros.

Marienhoff ${ }^{29}$, com a propriedade que lhe é particular, sustenta que a idéia de que a soberania implicaria em infalibilidade. Além de ser "equivocada", consistia, antes de tudo, em "um absurdo". Invocando a autoridade de Rodolfo Bullrich, afirma que "soberania nunca pode ser sinônimo de impunidade. Soberania significa o exercício de poderes superiores dentro do direito, dentro das normas legais ou constitucionais que fixam a conduta a ser observada pelos funcionários do Estado". Destarte, "todo ato praticado à margem da lei ou da constituiçâo será um ato inválido, não se podendo, de nenhuma forma, invocar-se, para sua validez, a soberania do Estado". Termina a exposição de seu raciocínio afirmando que "se soberania não implica 'infalibilidade', menos ainda implicará 'impunidade", por onde fundamenta a assunção da tese da responsabilidade estatal por seus diversos comportamentos.

Outrossim, mesmo ante a tais questionamentos, a idéia de um Estado irresponsável, assombrosamente, perdurou até tempos bem recentes, posto que só foi definitivamente rechaçada nos Estados Unidos da América em 1946 (Federal Tort Clain $A c t$ ) e na Inglaterra em 1.947 (Crown Proceeding Act) - em ambas as oportunidades, pela ruptura da via legislativa.

$\mathrm{Na}$ Inglaterra o princípios do the king can do no wrong, que operava no plano material, era acompanhado pelo princípio da imunidade judicial da Coroa (doutrina da non suability) que atuava no plano processual - a própria formação da litis dependia da prévia formulação de um petition of rights, que a Coroa podia admitir mediante uma fiat justitia - entretanto, os casos de responsabilidade extracontratual seguiram ficando de fora da petition of rights (mesmo após a reforma legislativa de 1860).

27 DI PIETRO, Maria Sylvia Zanella. Op. cit., p. 525.

28 Aquilo que agrada ao príncipe tem força de lei.

29 MARIENHOFF, Miguel S. Tratado de Derecho Administrativo. Buenos Aires, Abeledo-Perrot, 1.997 , t. IV, p. 720. 
Semelhante foi o processo de evolução do direito norte-americano, a despeito da crítica de que em uma República é incompativel a vigência de tal princípio (the king can do no wrong). Primeiro observou-se, face do aumento de reclamações perante o Congresso de pleitos lastreados em um de seus atos (private bills), a criação, em seu seio (Congresso), de um órgão assessor especializado (Court of Clains); em 1922. surgiu um verdadeiro tribunal, denominado Small Tort Clains Act, até que em 1946 se aprovou a Federal Tort Clains Act, que como sua irmã gêmea inglesa (Crwon Proceeding Act), reconhece a responsabilidade do Estado (esta responsabilidade é configurada como uma responsabilidade por fato de outrem - vicarious liability).

$\mathrm{O}$ afastamento da tese do Estado irresponsável encontrou sérias resistências mesmo na Europa Continental, já sob a égide do Estado de Direito. Observa-se que, mesmo no limiar do século XX, alguém do cabedal de Laferrière ainda afirmava que "o próprio da soberania é impor-se a todos sem compensação", fato que demonstra a contaminação, no ideário moderno. dos prejuízos dos tempos medievais, "apesar destas idéias repugnarem positivamente o espírito da época" ${ }^{30}$.

A superação da tese da irresponsabilidade do Estado, que se iniciou em fins do século XIX e se solidificou, especialmente, após o advento da Primeira Grande Guerra Mundial, num momento inicial foi substituída por critérios e princípios extraídos do direito civil, sustentando-se a responsabilidade patrimonial e extracontratual do Estado na chamada teoria da culpa. Este é o segundo período da evolução do instituto, conforme anteriormente manifestado.

\subsubsection{Teorias civilistas - a teoria da culpa (primeiro momento)}

Seguiu-se um segundo período, que substituiu a idéia da irresponsabilidade estatal decantada. Nesta oportunidade, erigiu-se o entendimento de que a responsabilidade do Estado apoiava-se na idéia de culpa, extraída da construção que o direito civil implementou quanto ao assunto. Num primeiro momento, distinguia-se, para a responsabilização, os assim chamados atos de império dos atos de gestão. Aqueles (atos de império), eram os que a Administração Pública praticava assumindo o papel de Poder Público, se valendo de "todas as prerrogativas e privilégios de autoridade e impostos unilateral e coercitivamente ao particular independentemente de autorização judicial, sendo regidos por um direito especial, exorbitante do direito comum, porque os particulares não podem praticar atos semelhantes" 31 ; não eram os atos de império suscetíveis de gerar responsabilidade, possível somente à segunda categoria de atos declinada (atos de gestão) - esta categoria de atos (de gestão) englobava aqueles praticados pela Administração Pública que não continham os predicamentos observados nos chamados atos de império; nos atos de gestão a Administração Pública atuava em situação de "igualdade com os particulares, para a conservação e desenvolvimento do patrimônio público e para a gestão de seus

30 ENTERRÍA, Eduardo García de; FERNÁNDEZ, Tomás-Ramón. Op. cit., t. II, p. 358.

31 DI PIETRO, Maria Sylvia Zanella. Op. cit., p. 525. 
serviços" 32. Como não há diferença de situação entre a Administração Pública e o particular, aplica-se, segundo a regra então estabelecida, o direito comum.

Os atos de gestão também eram provenientes do Estado, entretanto, personificado na figura de seus prepostos (servidores). Distiguia-se, face da construção empreendida, a pessoa do soberano da pessoa do Estado - aquele (soberano) continuava insuscetível de praticar ilícitos e perpetrava atos de império; este (Estado) praticava atos de gestão por meio de seus funcionários (empregados do Estado).

Note-se que, mesmo sob a égide do Estado de Direito a tese da irresponsabilidade do Estado ainda era cultuada. Ao admitir-se a separação de uma ou outra categoria de atos para efeito de se inculcar responsabilidade patrimonial ao Estado, ao mesmo tempo em que havia aparente ruptura com o modelo medieval, a contrário senso se sustentava o princípio basilar dos regimes de arbítrio, consubstanciado na expressão the king can do no wrong. Os atos de império, praticados pelo soberano $(R e i)$, não responsabilizavam o Estado, mesmo quando causassem dano aos particulares (o Rei não comete ilícitos ...). Marienhoff ${ }^{33}$, ao atentar para as "situações quase permanentes de risco" derivadas do intervencionismo administrativo na esfera do direito dos administrados, anota que, na era atual, vivenciamos uma situação quase que contrária à observada no assim chamado Estado Liberal, cuja intervenção "deixava quase livre a esfera de atividade dos administrados, circunstância que, então, explicaria a tolerância da idéia de "irresponsabilidade" do Estado".

Rivero ${ }^{34}$, por sua vez, justificava a debatida solução no fato de que o Estado Liberal, justamente por limitar "de forma estreita" seu modo de atuação e o âmbito de suas atividades, "tinha, relativamente, poucas ocasiōes de causar danos", sustentação que talvez alicerce a adoção da teoria da dicotomia dos atos estatais, para fins de responsabilidade, em atos de império e atos de gestão.

Não obstante de, àquela oportunidade, a teoria em debate constituir importante avanço quanto à evolução do tema da responsabilidade extracontratual do Estado, é certo que logo se reconheceu a completa impossibilidade de se operar a divisão personalidade estatal.

\subsubsection{Teorias Civilistas - a teoria da culpa (segundo momento)}

Da responsabilidade pessoal dos servidores, passou-se a uma outra fase, por meio da qual, sempre calcada na idéia de culpa (responsabilidade subjetiva), admitiu-se a responsabilização do Estado não só pelos atos de seus servidores, conforme até então era aceito, como também pelo funcionamento dos serviços públicos; afastada a dicotomia observada para aquele efeito entre os atos de império e os atos de gestão - até mesmo pela impossibilidade de enquadramento dos atos em um ou outro tipo ideal - procurou-se equiparar a responsabilidade do Estado à do patrão ou comitente pelos atos de seus empregados ou prepostos.

33 MARIENHOFF, Miguel S.. Op. cit., t. IV, p. 722.

34 RIVERO. Jean, Direito Administrativo. Coimbra, Almedina, 1.980, p. 307. 
Restou consignado na história doutrinária do direito público, então, a chamada teoria da culpa civil ou da responsabilidade subjetiva, que no Brasil veio consagrada pelo expresso no artigo 15 do Código Civil, editado em 1916.

José Aguiar Dias ${ }^{35}$, tomando por paradigma a orientação de Menegale no sentido de que seria imperativo interpretar a qualidade de representante como significativa de que o representante agiu em função da representação, demonstra, outrossim, a "artificiosidade" da teoria da culpa, que tomava como seu substrato único e exclusivo a culpa do funcionário. Desta forma, segundo o correto apontamento do autor, não se poderia falar de verdadeira culpa do Estado, que responderia por danos causados a terceiros "porque o culpado é o seu funcionário".

Face da fragilidade daquela proposição. José Aguiar Dias ${ }^{36}$ aconselhava que, aceito o principio da culpa, o que "melhor se recomenda" era legitimar a responsabilidade do Estado sob este viés na idéia de que ele (Estado), não podendo praticar "materialmente" o ato danoso, se faz "substituir" por seus funcionários - "O Estado, como que, em última análise, o pratica por intermédio do funcionário".

Referida teoria (da culpa) lançou bases em alicerce delicado, que não lhe servia a sustentar. Caracterizada na figura do funcionário a mera condição de representante do Estado, não se poderia responsabilizá-lo por atos praticados em usurpação de poder, fora do campo de delimitação de suas atribuições, vez que tal categoria de provimentos são classificados por inexistentes. A responsabilidade só poderia ser inculcada ao preponente (Estado), com a conformação "à complicadíssima fabricação de artifícios, onde dominam as figuras de representação das presunções e da famosa culpa in eligendo, invocada mesmo quando o responsável prove, matematicamente, que fez a escolha correta" 37 .

De fato, estas e outras premissas que se tentaram construir a partir de teorias civilistas encontram óbice intransponível em fato absolutamente relevante: a responsabilidade do Estado é matéria de direito público e como tal possui regime jurídico próprio e diferenciado do direito comum. A despeito de não ser refratária às regras do direito civil, as exorbita e, algumas vezes, as derroga. Por esta razão, prima facie, se demonstra equivocado exprimir o instituto sob o rótulo de responsabilidade civil do Estado, quando melhor seria a ele designar de responsabilidade extracontratual do Estado ${ }^{38}$, responsabilidade administrativa ${ }^{39}$ ou, simplesmente, responsabilidade do Estado $^{40}$. Eisenmann ${ }^{41}$ também se posiciona desta maneira, ao doutrinar que

35 DIAS, José Aguiar. Op. cit., v. II, p. 655.

36 DIAS, José Aguiar. Op. cit., v. II, pp. 655-656.

37 DIAS, José Aguiar. Op. cit., v. II, p. 656.

38 DI PIETRO, Maria Sylvia Zanella. Op. cit., p. 523.

39 RIVERO, Jean. Op. cit., p. 307. Atentamos, porém, que a locução responsabilidade administrativa não atende totalmente as necessidades de delimitação do tema responsabilidade do Estado, porque exclui a possibilidade de reparação de danos decorrentes do exercício das funções jurisdicional e legislativa, como veremos mais adiante.

40 Esta expressão também é por demais imprecisa, vez que não separa a responsabilidade contratual da responsabilidade extracontratual, ou aquiliana, do Estado.

41 EISENMANN, Charles. Cours de Droit Administratif. Paris, Librarie Générale de Droit et Jurisprudence, 1983, T. II, pp. 791 e seguintes. 
"estas designações são muito mal acolhidas porque não evocam o todo, nem sugerem em que consiste a medida da instituição ou do apelo da locução responsabilidade civil. Outras locuções seriam bem melhores: reparação, restituição, compensação, indenização", vez que, para o autor, a expressão civil significaria reparação, que por sua vez remeteria à idéia de equivalência, a qual pode não ser atendida, por exemplo, nos casos de indenização por dano moral.

A locução civil, adicionada à expressão responsabilidade do Estado indica, ainda, uma contradictio in terminis e só vale mesmo para estabelecer um contraponto à responsabilidade penal, que a despeito de não ser eminentemente patrimonial, encerra a mesma idéia fundamental da responsabilidade privatística: a de reparação. Entretanto, é "de se notar que não se pode definir a responsabilidade civil por seu caráter meramente patrimonial, porque assim, ele constituir-se-ia numa medida de ordem patrimonial, afetando o patrimônio do responsável (...). Existem, por outro lado, sançōes penais que apresentam a mesma característica confiscatória" +2 .

Eisenmann ${ }^{43}$, além de atentar à hipótese transcrita, também adverte que o direito da responsabilidade civil é um direito de reparação de danos (prejuízos). E o sentido da locução civil, que se opõe a penal, faz indicar a responsabilidade jurídica, conforme a moral. A reparação de danos é uma coisa: a punição de infrações, porém. é outra.

Sem embargo de qualificar como sinônimas as locuções responsabilidade civil e obrigação legal de reparar o dano, obviamente excluindo para este efeito a responsabilidade contratual, o autor em epígrafe traz a lume interessante discussão que sustenta o que afirmamos anteriormente. É, pois, de seu magistério, que consiste em medida de rigor "estabelecer a distinção entre a idéia de reparação e a idéia de pena, a despeito de esta não ser uma tarefa fácil. A idéia de reparação implica em certas vantagens ao sujeito passivo do dano (beneficiário); esta observação permite indagar se a noção de equivalência está (ou não) incluida na noção de reparação. A reparação de dano moral em pecúnia é equivalência? Como falar de equivalência, e como apreciá-la? Destarte, civil significaria reparação, no mínimo - talvez, seria melhor chamar de vantagem. Estas designações são muito mal acolhidas porque não evocam o todo. nem sugerem em que consiste a medida da instituição ou do apelo da locução responsabilidade civil. Outras locuções seriam bem melhores: reparação, restituição, compensação, indenização. Esta defeituosidade se revela mais flagrante quando empregada no direito público, porque a locução civil tem uma pluralidade de sentidos (oposto a penal; oposto a público ...) - o que faz evidente a incompatibilidade do termo civil com o termo público (...).".

Tecidas estas considerações, de se encaminhar o estudo do tema à luz de sua disciplina própria, sob a regência do direito público, partindo-se da evolução do mote civilista que se empregou à teoria geral da responsabilidade do Estado.

42 EISENMANN. Charles. Op. cit., p. 791.

43 EISENMANN. Charles. Op. cit., p. 793. 


\subsection{4 - Teorias Publicistas}

Vencidas as resistências quanto à possibilidade de responsabilização do Estado. após a adoção da solução civilista, construiu-se uma sólida estrutura de base publicista acerca do instituto. A despeito da síntese evolutiva discriminada anteriormente acompanhar momentos históricos datados, é certo, entretanto, que entre cada um dos períodos em que restaram solidificados os princípios regentes da responsabilidade do Estado inexistiu um divisor de águas concreto.

Ainda sob o influxo da idéia de irresponsabilidade, observou-se, na França, um abrandamento do rigor do princípio, com a edição da Lei de 28 do Pluvioso do ano VIII, que "permitia a reparação dos danos causados por obras públicas" inaugurou o que Moreau chamou de "idade teológica" 45. .

Desde que a Constituição napoleônica do ano VIII, em seu artigo 75, prescreveu a exigência de uma autorização administrativa (requisito sine qua non) para que se demandasse um funcionário na via civil (suposta conseqüência do princípio da separação de poderes) - a despeito de dita autorização ter se constituído em um obstáculo importante na responsabilização pessoal dos agentes - nota-se, a partir de então, que o direito "corrige" ${ }^{46}$ o princípio da irresponsabilidade ao admitir a responsabilização dos funcionários por atos relativos às suas funções.

O rigor da exigência da autorização do Conselho de Estado contido na norma - sistema "chamado de garantia administrativa dos funcionários" ${ }^{47}$ - que na aparência erigia-se como óbice quase intransponível ao ressarcimento de danos sentidos pelos particulares a partir da ação estatal, não impediu que a mesma, outrossim, se constituísse no embrião que, posteriormente, abriu as portas para que a responsabilidade patrimonial recaísse sobre a Administração.

O Conselho de Estado, órgão competente a decidir sobre a dita autorização, sistematicamente a negava, salvo em casos nos quais se apreciasse uma falta pessoal flagrante do agente. Assim, teve o Conselho de Estado de desenvolver a tese paralela de que no caso de uma falta de serviço impessoal, as ações poderiam ser dirigidas contra o Estado, nos tribunais administrativos. Esta distinção básica foi o motor da evolução do instituto, que progressivamente vai restringir os pressupostos de falta pessoal, de modo a caracterizar ausência de toda relação com o serviço — o chamado faute détachable - consagrado no arrêt Pelletier de 1.873. Em todos os outros casos, mesmo naqueles em que coexistiam as faltas pessoais com situações que não a abrangiam - a chamada acumulação de responsabilidades — passou-se a se considerar "diretamente responsável a Administração" "48 pelas faltas cometidas por seus agentes.

44 RIVERO, Jean. Op. cit., p. 307.

45 ENTERRÍA, Eduardo García de: FERNÁNDEZ. Tomás-Ramón. Op. cit.. t. II, p. 362.

46 RIVERO. Jean. Op. cit., p. 311.

47 RIVERO. Jean. Op. cit., p. 311.

48 ENTERRÍA, Eduardo García de: FERNÁNDEZ. Tomás-Ramón. Op. cit., t. II, p. 362 e seguintes. 
Entretanto, foi o arrêt Blanco ${ }^{49}$, de 1.873, com precedentes no arrêt Rotschild de 1855, que afirmou, pela primeira vez, com grandes cautelas, o princípio geral da responsabilidade da Administração sobre bases autônomas, ao afirmar que "a responsabilidade que pode caber ao Estado quanto aos danos gerais causados aos particulares por atos que ele emprega no serviço público (...) não é nem geral, nem absoluta; tem suas regras especiais (...)". Para Rivero ${ }^{50}$, a fórmula consagrada no acórdão em testilha, por mais restritiva que possa parecer, "nem por isso deixa de consagrar a existência de uma responsabilidade do poder público independente de qualquer texto".

O mesmo Rivero, contudo, adverte que, pela inteligência então construída, é necessário distinguir dentre os fatos danosos, aqueles que "podem ser apreciados abstraindo de qualquer exame do comportamento da Administração" e que constituem "fatos pessoais do autor" que se abstraem do exercício regular da função pública, que por esta razão, "envolvem responsabilidade perante os tribunais comuns em termos do direito privado", daqueles que qualifica de "fatos danosos não separáveis" que podem constituir falta de serviço que envolve "perante tribunais administrativos a responsabilidade das pessoas públicas", em relação ao que, o arrêt Blanco afirmou o princípio, pouco tempo após a decisão de o arrêt Pelletier ter sido proferida. Daí falar-se de acumulação de responsabilidades, posto que o direito positivo consagrava a existência de "uma responsabilidade pessoal do agente", por suas faltas pessoais, e uma "responsabilidade da pessoa pública" nos outros casos em que aquela (responsabilidade pessoal do agente) não era sentida.

As duas responsabilidades - pessoal do agente e da pessoa pública - não se excluem, coisa que restou solidificada a partir do que restou decidido pelo arrêt Anguet, de 1911.

$\mathrm{O}$ aperfeiçoamento do instituto não cessou mais, e se estendeu a todos os tipos de serviços, incluindo os que importam exercício de autoridade (polícia), na conformidade do arrêt Tomaso Greco de 1905, que inicia o que Moreau chamou de "idade positiva" ${ }^{51}$. A responsabilidade extracontratual do Estado se estende a todos os tipos de danos, sempre que sejam certos, ainda que futuros, ou, inclusive, morais, se

49 Referido acórdão conheceu de ação na qual a jovem Agnès Blanco demandava o Estado, de modo a inculcar-lhe responsabilidade, em razão de, ao atravessar uma rua na cidade de Bourdeaux, ter sido colhida por uma vagonete da Companhia Nacional de Manufatura de Fumo. Seu pai intentou ação de indenização civil contra o Estado sustentando o princípio de que ele é responsável por prejuízos causados a terceiros, em decorrência de ação danosa de seus agentes. Suscitado o conflito de competência entre a jurisdição comum e a justiça administrativa (contencioso administrativo). o Tribunal de Conflitos decidiu que a controvérsia deveria ser solucionada pelo tribunal administrativo, vez que o objeto da ação concernia no conhecimento de responsabilidade decorrente do serviço público. Mais que isto, fixou-se entendimento no sentido do qual a responsabilidade do estado não pode reger-se pelos princípios do Código Civil, porque se sujeita a regras especiais que variam conforme as necessidades do serviço e a imposição de conciliar os direitos do Estado com os direitos privados.

50 RIVERO, Jean. Op. cit., p. 308.

51 ENTERRÍA. Eduardo García de: FERNÁNDEZ, Tomás-Ramón. Op. cit., t. II, p. 363. 
permitirem estimativa em dinheiro (arrêt Dame Durand de 1.949); prejuízo estético (arrêt Morell de 1942); sofrimentos físicos excepcionais (arrêt Bondurand de 1.954) — perdas de pai, mãe ou filho, todos eles debaixo da fórmula genérica perturbações graves das condiçōes de existência.

O sistema definido segue apoiando-se na idéia de falta (noção tradicional de culpa), com algumas importantes correções - o pressuposto é uma falta, que, entretanto, por ser uma falta do próprio serviço - não é necessário individualizar qual. No direito francês, ainda não se chegou, como profetizava Duguit $t^{52}$, a edificar-se a responsabilidade do Estado sobre um fundamento objetivo.

$\mathrm{Na}$ Alemanha, o direito da responsabilidade patrimonial da Administração começou formulando-se como uma responsabilidade indireta, consequiência de atos ilícitos de funcionários e agentes; a Constituição de Weimar, que influenciou a Constituição espanhola de 1931, prescreveu em seu artigo 131 que se a potestade pública confiada a um agente infringe deveres do cargo perante terceiros, a responsabilidade alcança, por princípio, o Estado ou a corporação a que pertence o funcionário - teoria da indenização do direito público;"junto a esta cobertura do dano ilícito, ao que se reserva expressamente o conceito e a expressão de responsabilidade patrimonial do Estado (Staatshaftung), se conhece o que a doutrina alemã e, por seu influxo, uma parte da italiana (Alessi) e espanhola (Garrido Falla) conhece pelo nome de indenização de Direito público (öffentlich-rechtlich Entschädigung)" ${ }^{53}$.

Referida construção teórica era qualificada por intervenções conforme o direito (rechtmässige Eingriffe). Enterría e Fernánde ${ }^{54}$ salientam, coisa que é por demais interessante, que aquelas intervenções, a partir da Constituição de Weimar, "começam a qualificar-se formalmente como expropriações em um processo que impulsiona a doutrina e é acolhido pelos Tribunais, de ruptura do modelo clássico da expropriação, ligado inicialmente à idéia de trespasse forçoso de direitos e de progressiva evolução expansiva do instituto expropriatório".

O fio condutor desta idéia de "sacrifício especial", cujo precedente legislativo foi o artigo 75 do Algemeines Landrecht prussiano de 1794, traz à consideração que o Estado deveria indenizar aqueles que sacrificam seus direitos e vantagens particulares no "interesse da comunidade". Observa-se aqui, o nascituro da teoria do risco, fundamento tese da responsabilidade objetiva do Estado, lastreada no "princípio da igualdade dos ônus e encargos sociais" 55 .

\subsubsection{Teoria da culpa do serviço}

De todo o expendido, é, pois, de se extrair, que da generalidade dos fundamentos do princípio da responsabilidade extracontratual do Estado, encarada a partir de uma ótica publicista, construíram-se algumas teorias que não somente situam uma abor-

52 Apud, ENTERRÍA, Eduardo García de; FERNÁNDEZ, Tomás-Ramón. Op. cit., t. II, p. 364.

53 ENTERRÍA. Eduardo García de; FERNÁNDEZ. Tomás-Ramón. Op. cit., t. II, p. 360.

54 ENTERRÍA, Eduardo García de; FERNÁNDEZ, Tomás-Ramón. Op. cit., t. II. p. 360.

55 DI PIETRO. Maria Sylvia Zanella. Op. cit., p. 527. 
dagem diferenciada da problemática. Mais que isto, permitem mesmo observar, de forma nítida, um traço evolutivo acerca assunto em comento. Por esta razão é que Cretella Júnior ${ }^{56}$ sustenta que as teorias publicistas sobre a responsabilidade do Estado também evoluíram, a exemplo do que ocorreu na evolução da teoria da irresponsabilidade para as teorias civilistas e mesmo quanto a tratativa empreendida a partir dos conceitos absorvidos das bases do direito comum.

A primeira destas teorias arquitetou-se sob a estrutura do que a doutrina convencionou chamar de teoria da culpa do serviço ou da culpa administrativa.

A culpa, em sentido amplo e nas bases da construção civilista do instituto jurídico, é baseada em um elemento humano; recai sobre a pessoa física do sujeito causador do dano. No direito público, informado por princípios próprios e diferenciados daqueles que regem o direito privado, a culpa do sujeito, incorporado na figura do funcionário, nem sempre poderá ser considerada, vez que nem sempre é possível identificar-se o agente, autor da ação danosa. Nas palavras de Cretella Júnior ${ }^{57}$, sob o influxo deste pensamento, "a ação humana, fonte de prejuízos, é que vai permitir a responsabilização do Estado, através do homem, do sujeito".

Em sendo impossivel imputar a culpa a alguém - a um funcionário - a solução, no direito administrativo, remeteu à consideração diversa daquela adotada como sustentáculo no direito civil. Sob as regras do último, não havendo culpa pessoal, não se pode falar em responsabilidade, vez que aquela (culpa), é pressuposto desta (responsabilidade). Já no direito público, excluída a culpa pessoal do agente, resta a chamada culpa do serviço, que é anônima por característica.

A teoria da culpa administrativa, também conhecida por teoria do acidente administrativo, lança bases nas seguintes premissas: os serviços públicos devem funcionar com regularidade; não podem parar, atrasar ou ser objeto de prestação imperfeita. Qualquer coisa que lhe altere o funcionamento traz, como consequêencia invariável, prejuízos aos administrados.

Rolland $^{58}$, de há muito já asseverava, outrossim, que o Estado fica obrigado a indenizar o administrado em razão da teoria da culpa administrativa sempre que o não funcionamento, o funcionamento tardio ou o funcionamento irregular do serviço público puder se evidenciar a partir do cotejo em relação à média que poderia ser regularmente exigida para sua prestação, coisa que, se aprecia casuisticamente e de modo relativo.

\subsubsection{Teoria do risco integral}

Da teoria da culpa administrativa, passou-se - nomeadamente a partir da evolução da jurisprudência do Conselho de Estado francês e sem se perder o norte

56 CRETELLA JÚNIOR. José. Tratado de Direito Administrativo. Rio de Janeiro, Forense. 1.970, t. VIII, p. 57.

57 CRETELLA JÚNIOR. José. Op. cit., t. VIII, p. 59.

58 ROLLAND, Louis. Précis de Droit Administratif. Paris, Dalloz, 1.947, p. 363. 
traçado pela assunção daquela tese, é de se ressaltar - a adotar-se a teoria do risco, que "serve de fundamento para a responsabilidade objetiva do Estado" 59.

Os ônus da vida social devem ser repartidos por todos os membros da coletividade. Neste diapasão, escorreita a afirmação de Cretella Júnior ${ }^{60}$ de que todo prejuízo causado por fato ou ato da Administração deve ser entendido como um ônus público imposto pelo Estado ao particular que vive sob as regras de uma sociedade organizada. Contudo, esse ônus deve se apresentar uniforme e atingir, de maneira igualitária, a todos os que compõe a comunidade administrada. No caso de uma pessoa, ou de um grupo determinado de pessoas experimentar, de forma excepcional e injusta, um ônus maior que o suportado pelos demais membros da sociedade, emerge, ipso facto e sem a necessidade de perquirir-se acerca da culpa (pessoal ou administrativa), a obrigação de indenizar.

Referida teoria lança âncoras num princípio basilar do direito público, que informa, da mesma forma, o direito como um todo: a igualdade. A isonomia, para o direito administrativo, exige que se observe a absoluta igualdade dos individuos diante dos encargos públicos; quando ocorre a hipótese supra transcrita, ou seja, quando o ônus da vida social recai com mais intensidade sobre uma pessoa ou um grupo determinado de pessoas, aquele equilibrio entre os encargos sociais, traço marcante da igualdade dos particulares perante o Estado, é rompido. Então, para que haja restabelecimento da situação de igualdade, o estado deve indenizar, com recursos do erário, os prejudicados pela situação. Uma vez indenizado o administrado, "tudo se passa como se a Administração - que é a síntese patrimonial de todos os contribuintes - repartisse por todos os demais membros da coletividade o quantum da indenização, levantada antecipadamente do orçamento, que é constituído inclusive pelos tributos pagos pelos membros da coletividade" 61 .

Nessa teoria, a idéia de culpa é substituída pela de "nexo de causalidade entre o funcionamento do serviço público e o prejuízo sofrido pelo administrado". Não se cogita se o serviço público tenha ou não funcionado ou tenha funcionado bem ou mal, de modo regular ou irregular. Entende-se, sob este viés, a responsabilidade como consequiência do risco criado, como resultante do próprio fato (no caso, como resultante da ação do Estado). A teoria do risco, também designada teoria da responsabilidade objetiva, deixa de lado, como o próprio nome indica, o elemento subjetivo - a culpa - que é sempre "pessoal, subjetiva, atribuída sempre a uma pessoa". O elemento risco, a contrário senso, é lastreado, sempre, no princípio da causalidade, porque ocasiona um desequilíbrio" um desequilíbrio no patrimônio do prejudicado. Por isto é que se lhe inculca o caráter objetivo, impessoal ${ }^{62}$.

Estas, pois, são as bases da teoria do risco integral, que colocando de lado a "investigação do elemento pessoal, intencional ou não, preconiza o pagamento pelos 
danos causados, mesmo tratando-se de atos regulares, praticados por agentes no exercício regular de suas funções" 63 .

Há quem ${ }^{64}$, no entanto, faça distinção entre risco administrativo e risco integral, observando uma divisão da teoria estudada (teoria do risco integral). Yussef Cahali ${ }^{65}$, todavia, esclarece que apontada divergência não encontra fundamento na ciência jurídica e é meramente terminológica, posto que, segundo sua visão, tal distinção não se estabelece em função de uma distinção conceitual, mas simplesmente em função das conseqüências irrogadas a uma ou outra modalidade (risco administrativo e risco integral).

\section{A responsabilidade extracontratual do Estado no direito brasileiro}

Já tivemos a oportunidade de nos manifestar anteriormente que nosso direito em matéria de responsabilidade extracontratual do Estado sempre foi positivista ${ }^{66}$.

Assim é que, tanto a constituição do Império, quanto a primeira constituição republicana (1.891), não inseriram em seus textos referência expressa à responsabilidade estatal, limitando-se a dispor sobre a responsabilidade individual de seus agentes.

O Código Civil de 1.916, adotando a teoria subjetiva, informadora do princípio na época em que foi elaborado, consagrou em seu texto, mais especificamente em seu artigo 15 que "as pessoas jurídicas de direito público são responsáveis pelos atos de seus representantes, que nessa condição causem danos a terceiros, procedendo de modo contrário ao direito, ou faltando ao dever prescrito em lei, mas cabendo ao Estado o direito regressivo contra aqueles".

Este fato acirrou as divergências já existentes entre aqueles que aceitavam a teoria subjetiva da culpa e os que adotavam a teoria do risco, sendo certo que a primeira corrente encontrava no texto normativo em epígrafe a aparente consagração de suas convicções.

A constituição de 1.934, por seu turno, adotou a tese da responsabilidade solidária, o que foi recepcionado pela Carta de 1.937.

Foi, entretanto, a lei fundante promulgada em 1.946 que alçou ao cânone constitucional a teoria da responsabilidade extracontratual do Estado. Foi ela a primeira Carta a tratar da matéria das responsabilidades das pessoas jurídicas de direito público de modo a impedir a possibilidade do legislador ordinário pretender reavivar teses já superadas e que insistiam em informar o dia-a-dia das relações traçadas naquele nível e que contemplavam de forma absurda, regalias principescas àquela categoria de sujeitos.

63 CRETELLA JÚNIOR. José. Op. cit., t. VIII, pp. 68-69.

64 MEIRELLES, Hely Lopes. Curso de Direito Administrativo Brasileiro. São Paulo, Malheiros, 1.996, p. 562.

65 CAHALI, Yussef Said. Responsabilidade Civil do Estado. São Paulo, Malheiros, 1.995, p. 40.

66 SANTOS NETO, João Antunes dos. Op. cit., pp. 23-29. 
Justamente em face desta nova ordem implantada, pela qual substituiu-se a responsabilidade individual dos servidores públicos pela responsabilidade genérica da Administração é que a orientação subjetivista do Código Civil foi modificada (artigo 194) acolhendo-se, àquela oportunidade, a teoria objetiva do risco administrativo, fato que persistiu com o advento da Constituição de 1.967 (modificada pela Emenda No. 1 de 1.969).

A vigente constituição, de 05 de outubro de 1.988 , contudo, foi além e consagrou, em seu artigo 37, parágrafo sexto, a teoria da responsabilidade do extracontratual Estado em moldes gerais e não exclusivo de nenhuma matéria, ao prelecionar que "as pessoas jurídicas de direito público e as de direito privado prestadoras de serviços públicos responderão pelos danos que seus agentes, nessa qualidade, causarem a terceiros, assegurado o direito de regresso contra o responsável, nos casos de dolo ou culpa". No dispositivo constitucional, encontram-se insertas duas regras: "a da responsabilidade objetiva do Estado e a da responsabilidade subjetiva do funcionário" ${ }^{67}$.

Entretanto, existem divergências doutrinárias quanto à interpretação da regra constitucional em testilha, no que tange à teoria adotada: Há quem entenda que a disposição consagra a teoria do risco administrativo, onde o dolo ou culpa só é exigido em relação ao agente.

Também se observa divergência quanto à fixação da responsabilidade decorrente de ações comissivas e omissivas do Estado. Caio Tácito, citado por Celso Antonio Bandeira de Mello $^{68}$ entende que só há responsabilidade objetiva do Estado quando a conduta for comissiva, pois só uma atuação positiva pode gerar, causar, produzir um efeito. Na hipótese de comportamento omissivo, a responsabilidade seria subjetiva. Celso Antonio Bandeira de Mello sustenta, também, que a responsabilidade do Estado por omissão só pode ocorrer na hipótese de culpa anônima, da organização e do funcionamento do serviço, que não funcionou ou funcionou mal ou com atraso. Trata-se da aplicação da teoria da culpa do serviço ou do acidente administrativo, que já foi objeto de estudo em momento anterior. Todavia, o autor acrescenta que outra hipótese de responsabilidade objetiva é a que resulta do fato das coisas, "ainda que estes sejam devidos a casos fortuitos".

O Código Civil de 2.002, em seu artigo 43, parece ter restringido a amplitude do dispositivo constitucional que consagra a responsabilidade objetiva do Estado, na conformidade do disposto por seu artigo 37 , parágrafo sexto, ao dispor que "as pessoas de direito público interno são civilmente responsáveis por atos de seus agentes que nessa qualidade causem danos a terceiros, ressalvado o direito regressivo contra os causadores do dano, se houver, por parte deles, culpa ou dolo".

Referido dispositivo exclui, ao mencionar somente as pessoas de direito público as pessoas jurídicas de direito privado prestadoras de serviço público, na conformidade do que vem disciplinado pelo artigo 175 da Constituição Federal.

67 DI PIETRO. Maria Sylvia Zanella. Op. cit., p. 529.

68 BANDEIRA DE MELLO. Celso Antonio. Curso de Direito Administrativo. São Paulo, Malheiros, 2.003 , p. 890 . 
Odete Medauar ${ }^{69}$, ao comentar o capitulado pela Constituição da República, debatendo a disposição com o que vem disciplinado novo Código Civil brasileiro, atenta para uma particularidade, que é de todo importante. As pessoas jurídicas de direito privado podem ou não estar inseridas na Administração; daí decorreriam dificuldades de enquadramento de algumas das pessoas jurídicas que compõem o que se convencionou chamar de Administração indireta, vez que a maioria delas, é "dotada de personalidade jurídica de direito privado". Como, na sua concepção, que adotamos como escorreita. o preceito constitucional estabelece "duas relações de responsabilidade" (uma do poder público e de seus delegados na prestação de serviços públicos perante a vítima do dano, de caráter objetivo, baseada no nexo causal, e outra, do agente causador do dano, perante a Administração ou empregador, de caráter subjetivo, baseada no dolo ou culpa), e tomando-se as dificuldades de definição do conceito de serviço público, que possui, segundo a extensa construção doutrinária que se formou quanto ao objeto, uma concepção ampla e outra restrita (alguns, também empreendem a definição de serviço público um entendimento restritíssimo), nota-se que uma certa confusão poderia se formar na delimitação do espectro das disposições que regem o instituto da responsabilidade aquiliana do Estado em nosso direito pátrio atual.

Desta forma, observa-se que além das dificuldades apontadas, também é relevante colacionar que outras podem surgir "em virtude do contraponto entre serviço público e atividade econômica quanto à atuação das empresas públicas e das sociedades de economia mista" 70 .

Para o afastamento de eventuais dúvidas que podem surgir face da complexidade do tema em estudo, a autora aponta "alguns indicadores que podem auxiliar na tarefa" ${ }^{71}$, citando dispositivos da própria Constituição Federal e de leis que têm por missão a atribuição, a determinadas atividades, da condição de serviço público. Destarte, indica como referência a servir para aquele mister, o artigo 30 , inciso $\mathrm{V}$, da Constituição da República, bem como o artigo $1^{\circ}$ da Lei 9.074/95. O primeiro dos dispositivos trata da competência dos Municípios para a organização e prestação, diretamente ou sob regime de concessão ou permissão, de serviços públicos de "interesse local", aí incluídos o de transporte coletivo, que por expressa disposição constitucional, têm caráter essencial. O segundo concerne a sujeição ao regime de concessão, ou, "quando couber", ao de permissão, dos serviços e obras públicas de vias federais, obras ou serviços federais de barragens, contenções, eclusas, diques e irrigações, estações aduaneiras e outros terminais alfandegários de uso público, não instalados em área de porto ou aeroporto e os serviços postais.

Da mesma forma, serve de referência ao arranjo de eventual problemática. os expressos termos do artigo 175 da Constituição Federal, que consagra como sendo de incumbência do Poder Público, na forma da lei, diretamente ou sob o regime de concessão ou permissão, a prestação de serviços públicos. Acrescentamos, no en-

69 MEDAUAR, Odete. Op. cit., p. 397.

70 MEDAUAR, Odete. Op. cit., p. 397.

71 MEDAUAR, Odete. Op. cit., p. 397. 
tanto, que na via contrária, o artigo 173 da lei maior também se presta ao esclarecimento de eventuais controvérsias que podem surgir quanto à questão. Referido artigo trata da chamada atividade econômica industrial ou comercial explorada diretamente pelo Estado, quando "necessária aos imperativos de segurança nacional ou a relevante interesse público". Assim, no caso de prestação de serviços não industriais ou comerciais, ou seja, no caso de prestação de serviços públicos considerados in specie (artigo 175 da C. F.), a responsabilidade é objetiva, na forma do prelecionado pelo artigo 37, parágrafo sexto da Carta. Quando a hipótese se subsumir àquilo que a doutrina chama de serviços comerciais ou industriais prestados pelo Estado (artigo 173 da C. F.), a responsabilidade é subjetiva nos moldes do que vem regulado pelo direito civil.

Yussef Cahali $^{72}$, por seu turno, direciona a atenção dos operadores do direito para outra situação de extremo relevo. Trata-se da distinção que deve ser feita entre a responsabilidade que atinge as pessoas jurídicas de direito privado que não integram a Administração Pública, nos caso de concessão, permissão de serviço público ou autorização de serviço e aquela que alcança as que mantêm, também com a Administração, contrato de prestação de serviço ou obra pública. Na primeira das hipóteses a solução aponta para a consagração da responsabilidade objetiva "nas atividades vinculadas ao serviço", restando ao regramento das normas de direito civil (responsabilidade subjetiva) os danos que resultem de outras atividades que não têm vinculação com o serviço; na segunda hipótese, admite-se a "responsabilidade solidária da Administração por má escolha do particular prestador do serviço, por ausência e falha na fiscalização, desde que comprove o nexo causal entre essa conduta e o dano". A responsabilidade objetiva inculcada a pessoas jurídicas de direito privado que celebram com a Administração contratos de prestação de serviços, também pode ser solidária, nos mesmos moldes apontados, desde que comprovada a negligência daquela (Administração) "na fiscalização do contrato ou na escolha do contratado" 73 .

No que tange a obras públicas realizadas por empreiteira privadas que mantém contrato com a Administração, aponta a doutrina ${ }^{74}$ como tendências atuais sobre responsabilização que, pelo fato da obra (existência da obra) responde somente a Administração; por dolo, imprudência, negligência, imperícia da empreiteira, pode a vítima escolher quem vai acionar, ou mesmo, acionar ambas.

A Administração é responsável não só pelos atos que seus agentes praticarem nessa qualidade, ainda que a conduta tenha sido abusiva ou excessiva, como também o é, nas "hipóteses de danos oriundos de agentes não identificados ou de falhas em máquinas, aparelhos, equipamentos (fato das coisas), sem possibilidade de atribuição a agente algum" "75. A Administração, como se pode ver, é responsabilizada não só por ações comissivas ou omissivas de seus agentes.

72 CAHALI, Yussef Said. Op. cit., pp. 151-152.

73 MEDAUAR, Odete. Op. cit., p. 398.

74 MEDAUAR, Odete. Op. cit., p. 398.

75 MEDAUAR, Odete. Op. cit., p. 399. 
O dispositivo da Constituição Federal em comento (artigo 37, parágrafo sexto) também consagra a responsabilidade pessoal do agente causador do dano, quando identificado ou identificável, que tenha agido com dolo ou culpa para a produção do resultado danoso. Vislumbra-se o estabelecimento da responsabilidade civil do agente perante a Administração que ressarce danos causados a terceiros. Para valer-se do direito de reparação, a Administração se utiliza do direito de regresso contra o agente que, do ponto de vista subjetivo pode ser responsabilizado, de modo a obrigá-lo a ressarcir o erário, sangrado com o pagamento de indenização de quem sofreu prejuízos por ato ou fato àquele (agente) imputável.

De se ressaltar, entretanto, que face da processualística brasileira, o direito de regresso deve ser exercitado com a observância da figura da denunciação à lide, que é obrigatória "àquele que estiver obrigado, pela lei ou pelo contrato, a indenizar, em ação regressiva, o prejuizo do que perder a demanda", na conformidade da previsão do artigo 70, inciso III, do Código de Processo Civil em vigor.

Referida norma, entretanto, não tem aplicação quando se discute, em ação própria, a responsabilidade extracontratual do Estado. Isto se afirma, sem possibilidade de engano, em razão de que é impraticável, à luz do ordenamento jurídico considerado de forma holística, misturar-se numa mesma demanda os institutos da responsabilidade objetiva (do Estado) e a responsabilidade subjetiva (do agente causador do dano). Não se discutindo a culpa na primeira das hipóteses suscitadas (responsabilidade objetiva), não se poderia exigir, em flagrante desrespeito aos direitos daquele que sofreu o dano, que aquela (culpa) integrasse a lide para os efeitos do exercício do direito regressivo da Administração, que, outrossim, não encontra óbice em acionar, na via própria, o agente causador do dano para os efeitos previstos no dispositivo constitucional estudado.

Em tempos recentes, o Governo brasileiro, por iniciativa da Advocacia Geral da União, apoiada pelo Ministério da Justiça, reuniu comissão especial de notáveis para que fosse elaborado anteprojeto de lei tendente a ordenar, de forma expressa, a responsabilidade civil do Estado. Referida comissão, presidida pelo insigne Professor Caio Tácito, e que teve como membros, Odete Medauar, designada relatora, Carlos Alberto Menezes Direito, Sérgio de Andréia Ferreira, Ivete Lund Viegas, João Francisco Aguiar Drumond, Thereza Helena de Miranda Lima e Yussef Said Cahali, ultimou proposta composta de vinte e oito (28) artigos, que visa contemplar o "regime geral sobre a responsabilidade civil do Estado, objetivando sistematizar o assunto e consolidar os tópicos doutrinários e jurisprudencialmente assentes", aliás, na forma explicitada em sua Exposição de Motivos.

$\mathrm{O}$ anteprojeto, que à aparência, assume contornos de lei nacional, cuja " $\mathrm{mol}$ dura" poderá ser integrada pela legislação específica, mesmo a já existente, procura manter-se fiel, como não poderia deixar de ser, aos preceitos do artigo 37, parágrafo sexto, da Constituição Federal. Desta forma, exclui a possibilidade de limitação do valor das indenizações, na conformidade da redação de seu artigo 26 , ainda que outros diplomas tenham feito previsão anterior nesse sentido.

Louvável a atitude, posto que a disposição constitucional vigente não estabelece qualquer tipo de restrição acerca do quantum indenizatório a ser apurado em cada caso concreto. Ademais, a regra do artigo 37, parágrafo sexto da Constituição Federal 
é norma de eficácia plena que inadmite limitações. Aliás, a doutrina, bem como a jurisprudência, desde muito tempo já apontavam, de forma pacífica, que o valor indenizatório devido pelo Estado em virtude do reconhecimento de sua responsabilidade aquiliana tem de ser apurada sob a égide da razoabilidade e, essencialmente, da proporcionalidade.

Entretanto, justamente pelo fato de a norma constitucional consagradora do princípio da responsabilidade objetiva do Estado no Brasil não ser limitada - ao contrário, como afirmado, é de eficácia plena - salta-nos a dúvida quanto a real adequação do capitulado pelo artigo $7^{\circ}$ do anteprojeto em testilha. Referido artigo, ao tratar das causas excludentes ou limitativas da responsabilidade, em seu parágrafo único traz previsão de consideração proporcional responsabilidades, no caso de mais de uma pessoa, além da pessoa estatal ou de quem lhe faças as vezes (nos casos já especificados no corpo deste trabalho, recepcionados pelo artigo $1^{\circ}$ e seus parágrafos, do anteprojeto), concorrerem ao evento danoso. Não obstante ser objeto do anteprojeto a consagração da responsabilidade objetiva quer nos parecer que não só as limitações evidentes que decorrem do prescrito no indigitado artigo $7^{\circ}$, como também as que decorrem do que vem disposto nos artigos $8^{\circ}$ e 25 (previsão de solidariedade de responsabilidades), são inconstitucionais, por trazerem previsão de delimitação de fronteiras à uma regra constitucional geral que não pode ser excepcionada por lei que lhe é hierarquicamente inferior.

Tanto no primeiro caso (proporcionalidade de responsabilidade), quanto no segundo (solidariedade entre co-responsáveis), não se atenta para o fato de que o Estado possui direito de regresso contra o agente que causar o dano, por ação ou omissão. Somente nesta seara, ou seja, quando do exercício efetivo do direito de regresso, é que a limitação de responsabilidade ou a solidariedade entre co-responsáveis poderia ser discutida, de modo a não contrariar a ordem constitucional estabelecida ${ }^{76}$. O mesmo, não obstante, se aplica ao prelecionado pelo artigo $1^{\circ}$, parágrafo sexto, do anteprojeto, nos casos previstos de responsabilidade solidária do Poder Público em relação aos oficiais de cartórios extrajudiciais.

$\mathrm{Na}$ última das hipóteses transcritas, ou a relação da qual resultam danos indenizáveis a terceiros dos oficiais de cartórios extrajudiciais decorre da delegação do Poder Público, e aí a responsabilidade é objetiva e pode ser imputada diretamente ao Estado, que terá, depois, o direito de regresso contra o delegado, ou a responsabilidade por aquela situação não decorre daquela relação de delegação, e neste caso a responsabilidade é civil, subjetiva e exclusiva dos oficiais "notariais" e de "registro" (redação original do anteprojeto), sem que o Estado participe da relação jurídica controvertida.

76 Paillet comunga desta opinião, ao afirmar, peremptoriamente que "As regras adotadas no quadro da responsabilidade sem falta não são, entretanto, as mesmas, já que dessa vez o caráter excludente do ato de terceiro vai sucumbir diante da vontade de beneficiar a vítima com um tratamento plenamente favorável: a administração não poderá ver sua responsabilidade atenuada invocando o ato de terceiro, ela deverá responder à vítima pela integridade do prejuízo, ficando ela livre para regressar contra o terceiro para obter uma compensação". PAILLET, Michel. La Responsabilité Administratif. Paris, Dalloz, 1.996, pp. 47-56. 
Também questionável, à luz da tormentosa distensão doutrinária e jurisprudencial que se observa quanto à matéria da responsabilidade do Estado, foi a adoção "da responsabilidade por causas específicas, bem como pelo fato do serviço" quando estas teorias, per se, não esgotam todas as possibilidades de ocorrência da responsabilidade considerada pelo prisma objetivo. Aqui aparenta haver mais uma limitação que se tenta impor por lei ordinária à preceito constitucional que não admite restriçōes.

Louvável a preocupação em se integrar como causas que geram responsabilidade do Estado o exercício da jurisdição e da atividade legislativa (artigos 15 a 19). Buscou-se, neste particular, o que de mais atual existe, não só na doutrina e jurisprudência pátrias, mas também se procurou integrar a nosso direito. prescrições que já encontram positividade em países estrangeiros, nomeadamente europeus. Entretanto, resta a dúvida, que só será dirimida caso as disposições passem a integrar nosso ordenamento, de que as previsões empreendidas são, de fato, suficientes a contemplar com justiça todos os casos de responsabilidade estatal derivada daquelas atividades ${ }^{78}$, incluída a dos órgãos de assessoramento legislativo que nossa Constituição denomina de Tribunais de Contas.

Apontamos, outrossim, como mérito real dos esforços dispendidos na elaboração do anteprojeto a separação da função administrativa das funções institucionais do Poder Judiciário, do Poder Legislativo, dos Tribunais de Constas e do Ministério Público, coisa a qual, evidentemente, é digna de aplausos, dos mais efusivos.

\section{Causas excludentes da responsabilidade extracontratual do Estado}

Costuma-se apontar como causas excludentes da responsabilidade extracontratual do Estado a força maior, a culpa da vítima e o ato de terceiro.

O caso fortuito, que na esfera privatística, comumente, serve de excludente juntamente com as outras duas apontadas raramente (ou quase nunca) se presta a este mister quando a responsabilidade aquiliana é regida por princípios publicísticos. Isto ocorre porque a ocorrência o caso fortuito, em que o dano decorre de ato humano (no caso do próprio Estado) vem quase sempre associado ou a uma ação do Poder Público ou à uma omissão deste. A solução mais frequientemente empregada nestes casos é a de considerar a responsabilidade do Estado pelo prisma objetivo, ainda que o dano tenha origem em um comportamento omissivo, não obstante haver quem sustente, na conformidade com o que restou expendido anteriormente, que nos casos de omissão, a responsabilidade do Estado seria subjetiva ${ }^{79}$.

$77 \mathrm{Na}$ conformidade da redação da exposição de motivos do anteprojeto de lej.

78 Dentre outras coisas, não se observa prescrição de responsabilidade pela negativa de jurisdição, tema dos mais importantes e urgentes, face ao estágio de estrangulamento e morosidade do Poder Judiciário brasileiro. Da mesma forma, a omissão legislativa, que também é ponto crucial para o real desenvolvimento do país, restou esquecida.

79 C. f., p. 23 deste. 
Outrossim, é de todo relevante colacionar que "quanto ao alcance da força excludente de que é dotado o caso fortuito, é preciso observar que ela não saberia funcionar no quadro da responsabilidade sem falta" ${ }^{80}$.

Não discrepa deste posicionamento, aquele sustentado na lição de Yussef $\mathrm{Ca}$ hali ${ }^{8 !}$, para quem, com inspiração na doutrina de Themístocles Brandão Cavalcanti, "se a força maior provém de um fato externo, estranho ao serviço, o caso fortuito provém do seu mau funcionamento, de uma causa interna, inerente ao próprio serviço", coisa que impor-se-ia como fator de seu descarte para fins de exclusão da responsabilidade aquiliana do Estado.

A força maior, por seu turno, também -- e em determinados casos - pode não ser excludente de responsabilidade do Estado pela mesma razão. Ainda que ela tenha origem em um fato da natureza, inevitável, imprevisível, irresistível e estranho à vontade das partes, a responsabilização do Poder Público, mesmo em face de sua oposição, "poderá ocorrer se, aliada à força maior, ocorrer omissão do Poder Público na realização de um serviço" 82 .

Este, aliás, é o posicionamento sustentado na obra de Paillet, que preleciona que a força maior, como causa excludente da responsabilidade extracontratual do Estado. "é considerada, da mesma forma que no direito privado, como uma causa excludente em todos os regimes de responsabilidade, mesmo se em certos casos-limite esse efeito liberador possa não ser absoluto. Mas sua definição obedece a critérios tão rigorosos (irresistibilidade, imprevisibilidade e exterioridade) que ela será raramente admitida" ${ }^{83}$.

Quanto a esta hipótese, também há quem entenda, como Yussef Cahali, que a responsabilidade será, no entanto, subjetiva, lastrada na teoria da falta do serviço (faute du service). A mesma regra se aplica quando se tratar de atos de terceiros "o Estado responde se ficar provada sua omissão, a sua inércia, a falha na prestação do serviço público" $"$.

Também Diogenes Gasparini comunga desta opinião. Para este importante administrativista brasileiro, em certos eventos, o fato de os danos não terem sido causados pelo Estado não o libera da responsabilidade de indenizar se o comportamento público em relação a eles foi culposo ou danoso" 85 .

Quando houver culpa da vítima, a solução exige distinção entre culpa exclusiva daquela e culpa concorrente do Poder Público. No primeiro caso, o Estado não será responsabilizado e no segundo, o será, de forma mitigada, repartindo-se a sua responsabilidade com a da vítima.

Deve-se atentar, no entanto, que no sistema responsabilidade extracontratual do Estado, regido pelo direito público, nem sempre a solução se apresenta com a

80 PAILLET. Michel. Op. cit., pp. 47-56.

81 CAHALI, Yussef Said. Op. cit., p. 56.

82 DI PIETRO. Maria Sylvia Zanella. Op. cit., pp. 530-531.

83 PAILLET. Michel. Op. cit., pp. 47-56.

84 DI PIETRO. Maria Sylvia Zanella. Op. cit., p. 531.

85 GASPARINI. Diogenes. Direito Administrativo. São Paulo, Saraiva, 2.003, p. 844. 
facilidade que se imagina, posto que, na avaliação das consequiências liberatórias desta excludente, é necessário observar-se a quantificação da concorrência de culpas, na conformidade, aliás, das lições de Paillet $^{86}$ que nos adverte que em casos como o debatido, " esse efeito pode ser parcial ou total, em teoria, conforme a parte causal que se serviu desse ato na produção do dano. Na prática, na hipótese (freqüente) em que a responsabilidade da administração é investigada por falta e em que o ato da vítima tem em si mesmo um caráter faltoso".

Quanto ao ato de terceiro, é necessário levar em consideração que o dano tenha sido produzido, simultaneamente, por ato um da Administração e por ato de uma outra pessoa que não a vítima. Nestes casos, a solução que prima facie se apresenta é a de que a Administração deve ser condenada, somente, em relação à vítima, obviamente, na proporção do papel causal da falta que lhe é imputada, de modo que, para este fim, o ato do terceiro teria valor excludente. Contudo, conforme leciona Paillet, "essa solução pode ser criticada tendo em vista que ela obriga a vítima a intentar diversas ações enquanto se arrisca a tropeçar com a insolvabilidade do terceiro co-autor do dano e porque ela é contrária à posição adotada paralelamente pelo juiz civil. Com efeito, diante dele, os co-autores de um dano são suscetiveis de ser condenados pelo todo, o que só pode multiplicar os riscos de contradição de julgamento entre as duas ordens de jurisdição".

Aqui se vislumbra como a melhor solução, nos casos em que ocorre uma pluralidade de fatos cometidos por diversas pessoas públicas servindo em um mesmo serviço público, a vítima pode reclamar de uma dentre elas a reparação do conjunto do prejuízo.

A melhor construção erigida quanto ao tema, admite, pois, que a vítima possa reclamar a reparação completa da Administração. Por óbvio, máxime no regime brasileiro de responsabilidade objetiva, consagrado pelo artigo 37, parágrafo sexto, da Constituição vigente, que quando a Administração é assim ameaçada de pagar de algum modo no lugar de outrem (o terceiro), disporá "da possibilidade de regressar posteriormente contra o terceiro responsável. As regras adotadas no quadro da responsabilidade sem falta não são, entretanto, as mesmas, já que dessa vez o caráter excludente do ato de terceiro vai sucumbir diante da vontade de beneficiar a vítima com um tratamento plenamente favorável: a Administração não poderá ver sua responsabilidade atenuada invocando o ato de terceiro, ela deverá responder à vítima pela integridade do prejuizo, ficando ela livre para regressar contra o terceiro para obter uma compensação" 87.

Destarte, de se concluir que as causas excludentes de responsabilidade são, portanto, e de uma maneira variável, "estreitamente ligadas aos problemas de causalidade", como também, especialmente, na ocorrência da força maior e do caso fortuito, a questões de "imputabilidade" 88 .

86 PAILLET. Michel. Op. cit., pp. 47-56.

87 PAILLET. Michel. Op. cit., pp. 47-56.

88 PAILLET. Michel. Op. cit., pp. 47-56. 
Contudo, é de todo relevante colacionar que "cabe ao Estado provar a existência das mencionadas causas de exclusão de sua responsabilidade" ${ }^{89}$. Nos casos mencionados, o ônus da prova é invertido, cabendo ao Estado comprovar a ocorrência de uma das causas de exceção da afirmação de responsabilidade, que, nunca é demais repetir, é objetiva.

\section{Fundamentos da responsabilidade extracontratual do Estado}

Marienhoff ${ }^{90}$, com a propriedade que lhe particular, sustenta que o fundamento da responsabilidade do Estado se encontra no complexo de princípios próprios do Estado de Direito. Por esta razão, referido fundamento, será "sempre o mesmo em sua essência", qualquer que seja o órgão público - Executivo, Legislativo ou Judiciário - que cause a lesão jurídica ao administrado, independentemente da função exercitada. Basta, para sua evidenciação, a ocorrência de um dano e que este dano seja imputável, através de uma relação de causa e efeito, a uma ação ou omissão do Poder Público, posto que nem sempre a culpa é elemento exigível à sua caracterização.

A responsabilidade extracontratual do Estado, sob o influxo do direito público, qualquer que seja o órgão causador do dano, não vê alterada seu fundamento Este será, consecutivamente, o idêntico fundamento geral amplamente debatido, porque " $n a \tilde{a} o$ há um fundamento específico para a responsabilidade do Estado-Administrador, do Estado-Legislador ou do Estado-Juiz; o fundamento essencial é sempre o mesmo" 91 .

E este fundamento, na conformidade do que restou expendido, é a responsabilidade sem culpa, considerada de forma objetiva. Eisenmann ${ }^{92}$ ao estabelecer cotejo entre os fundamento da responsabilidade civil e da responsabilidade pública, reafirma o entendimento ao lecionar que, "no âmbito do direito público a situação doutrinária se encontra simplificada. Isso porque a unanimidade dos autores considera que a responsabilidade das pessoas públicas é uma responsabilidade sem culpa, sendo que uma relação causal entre o dano e a falta dos agentes públicos é a condição necessária para a caracterização de tal responsabilidade. $O$ debate acercado fundamento mediato da responsabilidade das pessoas públicas pode ser resumido à análise de duas teses: a tese da igualdade perante os encargos públicos e a tese da correlação entre os benefícios de uma ação e os encargos eventualmente decorrentes".

Por estes motivos é que a afirmação de que o fundamento geral da teoria da responsabilidade do Estado não exclui nerhuma de suas manifestações de suas manifestações. Afora, pois, o exercício da função administrativa, devemos, então,

89 GASPARINI, Diogenes. Op. cit., p. 845.

90 MARIENHOFF. Miguel S.. Op. cit., t. IV, p. 728.

91 MARIENHOFF. Miguel S.. Op. cit., t. IV, p. 729.

92 EINSENMANN, Charles. Op. cit., pp. 862-873 
relacionar o princípio às demais funções desempenhadas pelo Poder Público, considerado por esta natureza.

Acrescente-se, apenas, que $o$ "fundamento da responsabilidade patrimonial do Estado é bipartido, conforme seja ela decorrente de atos lícitos ou ilícitos" ${ }^{93}$. No primeiro dos casos (atos lícitos), o fundamento é a distribuição igualitária dos ônus $e$ encargos a que estão sujeitos os administrados. No segundo (atos ilícitos) o fundamento á a própria violação da legalidade.

\subsection{Responsabilidade extracontratual do Estado por atos legislativos}

Não obstante a identidade de fundamento apontada para a afirmação da responsabilidade do Estado, em qualquer de suas manifestações, observa-se, em relação aos atos típicos que decorrem do exercício da função legislativa, que a regra prevalente ainda é a da irresponsabilidade. Diversas justificativas são apresentadas para a defesa deste posicionamento, que, entretanto, não se apresentam revestidas de solidez suficientes à sua sustentação.

Maria Sylvia Zanella Di Pietro ${ }^{94}$, ao apontar os argumentos dos que defendem a tese da irresponsabilidade do Estado por atos legislativos, também indica os motivos que lhes servem ao rechaço. A primeira das teses defendidas lança âncora na velha questão da soberania: se o Poder legislativo atua em seu exercício (da soberania), podendo "alterar, revogar, criar ou extinguir situações", sem que se observe qualquer limitação que não decorra da Constituição, não poderiam seus atos, praticados sob esta égide, servir de móvel à responsabilização do Estado. Aos que sustentam este posicionamento, responde-se que, "mesmo exercendo parcela da soberania, o Legislativo tem de se submeter à Constituição", fato do qual faria emergir a responsabilidade estatal quando os atos legislativos editados fossem inconstitucionais. Também é com frequiência argüido que seria excludente da responsabilidade do Estado decorrente de sua atividade legiferante, o fato de as normas por ele editadas consubstanciarem regras gerais e abstratas, dirigidas "a toda a coletividade", das quais decorreriam ônus iguais para todos os que se encontram na mesma situação; entretanto, nem sempre o Estado edita normas com aquela característica, de forma que "deve responder por leis que atinjam pessoas determinadas, mesmo que se trate de normas constitucionais". em razão da quebra do decantado princípio da igualdade de todos perante os encargos sociais. Por derradeiro, há, também, aqueles que sustentam a irresponsabilidade legislativa no fato de que os cidadãos não poderem responsabilizar o estado por atos praticados por representantes (parlamentares) que eles próprios elegeram. A esta posição se pode combater com a justificativa de que a eleição do representante para ocupar vaga no parlamento "implica delegação para fazer leis constitucionais".

Segue. dentre nós, a posição do fundamento unitário da responsabilidade do Estado afirmado pelas lições de Marienhoff, o insigne Juary C. Silva ${ }^{95}$, fazendo de

93 GASPARINI, Diogenes. Op. cit., p. 838.

94 DI PIETRO, Maria Sylvia Zanella. Op. cit., pp. 531-532.

95 SILVA, Juary C.. A responsabilidade do Estado por Atos Judiciários e Legislativos". São Paulo, Saraiva, 1.985, p. 292. 
modo a exaltá-lo no princípio do Estado de Direito. Sob este viés, que também sustentamos, a problemática se resolve pela "submissão de toda atividade estatal ao Direito, concebendo-se este como criado pelo Estado, senão como algo que se coloca acima do Estado".

Sem embargo desta afirmação, se o fundamento derivado do princípio em testilha serve a sustentar a responsabilidade do Estado quanto aos atos decorrentes do exercício da função administrativa, não se poderia objetá-lo em relação àqueles provimentos - igualmente estatais - derivados do exercício da legislação. ou ainda de qualquer outra ação que tiver a mesma origem.

Aplicando-se, então a teoria do risco, como sustentáculo da responsabilidade do Estado, podemos, no melhor predicamento da doutrina de Jacqueline Morand Deviller $^{96}$, observar que são quatro as situações que, em teoria, não apresentam riscos ou perigo em si mesmas, mas que podem causar danos aos particulares, "ensejando, em certos casos, o direito de reparação às vítimas que, em nome do interesse geral, sofreram um sacrifício financeiro, o que acarreta uma ilegalidade diante dos órgãos públicos".

O dano deve apresentar, além do caráter de ser certo, também o de ser anormal e especial, e uma das situações que se encaixam na previsão da autora é justamente a da responsabilidade de fato decorrente das leis. Este fenômeno passou a ser sentido a partir da evolução da responsabilidade sem falta, que "permitiu a admissão da responsabilidade do fato decorrente das leis", a despeito, entretanto, desta modalidade de responsabilidade não ser costumeiramente reconhecida, a não ser "muito excepcionalmente".

No Brasil, a responsabilidade do Estado por leis inconstitucionais depende, no entanto, de "prévia declaração do vício pelo Supremo Tribunal Federal", proferida em ação direta de inconstitucionalidade, visto que nossa doutrina e, em especial, nossa jurisprudência, de tal modo inflexível se posicionam. Maria Sylvia Zanella Di Pietro $^{97}$, além de deixar a regra consignada, também se posiciona no sentido de que a mesma se aplica para atos normativos editados pelo Poder Executivo: se reconhecida sua inconstitucionalidade ou mesmo a sua ilegalidade, poderá "ensejar a responsabilidade do Estado, porque o dano é causado por ato emitido contra a lei, portanto fora do exercício de suas competências constitucionais".

Cretella Júnior ${ }^{98}$ sustenta que a responsabilidade do Estado pode surgir mesmo quando o ato danoso configurar uma lei constitucional. Isto ocorreria quando o ato legislativo com aquelas características atingir uma pessua determinada ou um número "restritíssimo" de pessoas determinadas, ainda que o propósito fosse o de editar uma lei geral ou abstrata.

96 MORAND DEVILLER, Jacqueline. Cours de Droit Administratif. Paris, Montchréstien, 2001. pp. 762-763.

97 DI PIETRO, Maria Sylvia Zanella. Op. cit., p. 532.

98 CRETELLA JÚNIOR. José. Op. cit., t. VIII, pp. 255-261. 
Tal conjuntura afigurar-se-ia possível e justificável quando lei constitucional causasse um "dano injusto" aos particulares, a exemplo do que é aceito, de forma pacífica, quando a ação estatal decorre de sua ação administrativa. Yussef Cahali ${ }^{94}$, após debater longamente o tema da responsabilidade do Estado por atos legislativos, indica sustentações doutrinárias e jurisprudenciais que alicerçam aquela posição. No mesmo sentido é a posição de Jacqueline Morand Deviller ${ }^{100}$, que indica algumas possibilidades da responsabilização a partir daquela origem comum (atos legislativos constitucionais).

\subsection{Responsabilidade extracontratual do Estado por atos judiciais e jurisdicionais}

Partindo-se do mesmo pressuposto referente ao fundamento universal da responsabilidade aquiliana do Estado, não discrepa do restou expendido no item anterior a solução que se pode empreender quando a responsabilidade estatal é imputada como razão de ressarcimento de danos que decorrem do exercício da jurisdição.

Nunca se observou sérias divergências quanto a discussão centrava foco na responsabilidade estatal relativa a danos ocasionados por atos judiciais que não implicassem o exercício da jurisdição. Marienhoff ${ }^{101}$ preleciona que desde tempos "muito antigos" havia a consideração favorável acerca da indenizabilidade dos danos causados pelo Estado aos administrados na sua "função de administrar a justiça". Referida admissão, entretanto. concernia à "reparação das vítimas de erro judicial", especialmente os ocorridos no âmbito penal.

Diferencia-se a ação do Estado-juiz, bipartindo-a em atos judiciais e atos jurisdicionais, para o efeito de se contemplar, debaixo da primeira das designações (atos judiciais), os provimentos do Poder Judiciário que se reportam à "administração da justiça em seus aspectos não jurisdicionais" ${ }^{102}$.

Quanto a este aspecto, nenhuma nota digna de menção se poderia trazer a lume, vez que sob a égide da locução atos judiciais, de fato, encontramos, nada mais do que a mera atividade administrativa típica, acerca da qual, atualmente, não mais se desconsidera a tese da responsabilização, face do desenvolvimento dos fundamentos que sustentam a matéria e que já foram objeto de exaustivo debate anterior.

Outrossim, quando a ação do Estado que enseja a responsabilidade por danos causados aos administrados é a que deriva diretamente do exercício da jurisdição. observamos tratamento absolutamente distinto.

Chegou-se mesmo a afirmar, com muita propriedade, aliás, que a irreparabilidade dos danos decorrentes da jurisdição constitui-se no último rincão da teoria da irresponsabilidade do Estado, consagradora do princípio do the king can do no wrong.

99 CAHALI, Yussef Said. Responsabilidade Civil do Estado. São Paulo, Malheiros, 1.995. p. 664 e seguintes.

100 MORAND DEVILLER. Jacqueline. Op. cit., p. 762-763.

101 MARIENHOFF, Miguel S.. Op. cit., t. IV, pp. 801-802.

102 ENTERRÍA, Eduardo García de; FERNÁNDEZ, Tomás-Ramón. Op. cit., t. II, p. 388. 
Já tivemos a oportunidade de afirmar anteriormente que "é grande a resistência à assunção desta possibilidade entre nós, fato que além de contrastar, parece mesmo opor-se a toda evolução da teoria da responsabilidade em face dos atos exarados pela Administração".

Salvo os casos de erro judicial, o ordenamento jurídico positivo brasileiro desconhece qualquer outra prescrição expressa que reconheça a tese contrária da irresponsabilidade, o que tem levado nossos tribunais a decidir com forte apego à um fetichismo corporativo que não condiz com a afirmação do Estado Democrático de Direito. Assim é que não nos furtamos em fixar posição acerca do que se detecta de nossa realidade, quando afirmamos que "é cediço que nossa jurisprudência arrima-se numa posição absolutamente ultrapassada e que vem sendo devidamente devastada por tendência concreta e universal contrária que impede qualquer justificação como aquelas que servem de sustentáculo à nossas Cortes, que com ares de inexplicável saudosismo autoritário, insistem em reafirmar que o Estado não responde por ato jurisdicional danoso senão quando houver expressa disposição legal nesse sentido (no caso, somente em face do que prescrevem os artigos 630 do CPP e $5^{\circ}$, inciso LXXV, da Constituição Federal)" ${ }^{103}$.

Não há justificativa para este tipo de posicionamento, posto que a regra geral consagradora do princípio da responsabilidade objetiva do Estado, na conformidade de sua redação, conforme prescrição do artigo 37 da Constituição Federal, não opera exclusão de qualquer espécie. "Note-se que o Poder Judiciário, mesmo em respeito aos mais comezinhos principios constitucionais, não pode excetuar-se das regras gerais consagradas pela Lei Maior, ainda que a mesma especifique em seu corpo parte desta responsabilidade - é inconcebivel admitir-se que a especialização desta parte de responsabilidade sirva para a exclusão de todo o resto, máxime sob a égide do princípio do Estado de Direito - assim, o artigo $5^{\circ}$, inciso LXXV, deve, ao contrário do que é sustentado pela jurisprudência, ser interpretado conjuntamente com o artigo 37, parágrafo sexto, ambos da Constituição Federal. Por esta razão. simplista. como a do entendimento contrário, é que o fato de o artigo $5^{\circ}$, inciso LXXV, da Carta estabelecer parte da responsabilidade estatal decorrente de atos emanados da função judiciária é que não nos seria lícito concluir, de forma a excepcionar o que de resto valeria aos demais Poderes, pela inaplicabilidade do regramento geral do artigo 37, parágrafo $6^{\circ}$, do mesmo texto normativo fundamental aos atos não alcançados por aquela regra específica, que aliás repetiu o que de há muito já prescrevera nosso Código de Processo Penal (artigo 630)" 104.

A exemplo do que restou debatido no item que tratava da responsabilidade do Estado por atos legislativos, também são insustentáveis as teses que afirmam a irresponsabilidade estatal em razão do exercício da jurisdição. Maria Sylvia Zanella Di Pietro ${ }^{105}$, da mesma forma que o faz quanto aqueles (atos legislativos), aponta aqui as sustentações, bem como suas respectivas antíteses, que repelem qualquer

103 SANTOS NETO, João Antunes dos. Op. cit., pp. 23-29.

104 SANTOS NETO, João Antunes dos. Op. cit., pp. 23-29. 105 DI PIETRO. Maria Sylvia Zanella. Op. cit., p. 533-535. 
possibilidade de consagração do posicionamento. Assim é que, quando a justificativa da irresponsabilidade apóia-se na soberania do Judiciário, responde com a mesma solução: a soberania é do Estado; o Executivo, o Legislativo e o Judiciário "não são soberanos porque devem obediência à lei e em especial à Constituição". A idéia de soberania não se contrapõe à de responsabilidade do Estado, que também se submete ao direito.

Igualmente inaceitável é a afirmação de que a responsabilidade do Estado pela prática de atos jurisdicionais violaria a independência dos magistrados, que não teriam isenção para julgar, posto que, se esse argumento fosse admissível, o Estado não poderia responder, também, por atos praticados pelo Poder Executivo, em relação aos quais não se contesta a sua responsabilidade.

A renomada autora também rebate a teoria de que o Estado seria irresponsável em razão dos atos jurisdicionais que brotassem de sua atividade, arrimada na incontrastabilidade da coisa julgada. Os cultores desta tese afirmam que a responsabilidade a ofenderia (incontrastabilidade); o rejeite desta posição tem substância na afirmação de que "no próprio direito brasileiro a força da coisa julgada sofre restrições na medida em que se admite a ação rescisória e a revisão criminal. Outrossim, mesmo os princípios da presunção da verdade da sentença trânsita em julgado (res judicata pro veritate habetur) e o da segurança jurídica não seriam abalados com a refutação da tese da irresponsabilidade" 106.

Também esta é a posição esposada por Edmir Netto de Araújo ${ }^{107}$, o que se constata quando leciona que "uma coisa é admitir a incontrastabilidade da coisa julgada, e outra é erigir essa qualidade como fundamento para eximir o Estado do dever de reparar o dano". Obtempera, também, o autor em epígrafe, que "o que se pretende é possibilitar a indenização ao prejudicado, no caso de erro judiciário, mesmo que essa coisa julgada não possa, dado o lapso prescricional, ser mais modificada".

A teoria da falibilidade dos juízes, a exemplo da teoria da independência da magistratura e a do risco assumido pelo jurisdicionado não merecem consideração.

106 Já tivemos a oportunidade de transcrever o pensamento de Maria Sylvia Zanella Di Pietro. nos seguintes termos: "No primeiro caso, observa, que no direito brasileiro, filiado ao sistema de base romanística, a presunção de verdade atribuida às decisões judiciais aparece enfraquecida, pois se trata de um sistema em que o precedente judiciário não tem qualquer força vinculante; são freqüentes as decisões proferidas em sentidos completamente opostos, ambas definitivas e envolvendo a aplicação e interpretação da mesma norma legal; como afirmar que a sentença contém uma verdade legal? Não é possível que ambas contenham uma verdade legal. Ou, pelo menos, trata-se de uma verdade legal que vale apenas para o caso concreto em que a decisão foi proferida. Face ao segundo aspecto, o da segurança jurídica, discorre a autora que haveria que se procurar um equilíbrio entre o ideal de segurança jurídica proporcionado pela coisa julgada e o princípio da justiça, que exige recomposição de prejuízos injustamente causados por uma sentença errada, especialmente em casos de erros judiciários reconhecidamente graves, fato que parece mais consentâneo, inclusive, ao princípio geral do Estado de Direito". Apud, SANTOS NETO, João Antunes dos. Op. cit., pp. 23-29.

107 ARAÚJO, Edmir Netto de. Responsabilidade do Estado por Ato Jurisdicional. São Paulo, Revista dos Tribunais, 1.981, pp. 137-143. 
As duas primeiras, ainda segundo Maria Sylvia Zanella Di Pietro ${ }^{108}$, porque "as garantias de que se cerca a magistratura no direito brasileiro, previstas para assegurar a independência do Poder Judiciário, em benefício da Justiça, produziram a falsa idéia de intangibilidade, inacessibilidade e infalibilidade do magistrado, não reconhecida aos demais agentes públicos e gerando o efeito oposto de liberar o Estado de responsabilidade pelos danos injustos causados àqueles que procuram o Poder Judiciário precisamente para que seja feita justiça". A colocação adequada da temática em desenvolvimento, vai ser encontrada na afirmação sempre lúcida da autora, para quem "o fato de o juiz ser falivel, como todos os seres humanos, não pode servir de escusa para o reconhecimento da responsabilidade civil do Estado, pelas mesmas razões que não serve de escusa a qualquer pessoa, na vida pública ou privada", com o que se há de concordar, sem qualquer margem de oposição ou ressalva a ser levantada.

Destarte, verifica-se inexistirem motivos que ensejam qualquer exceção à regra geral constante do disposto pelo artigo 37, parágrafo sexto. da Constituição Federal, que ao consagrar o princípio da responsabilidade objetiva do Estado, não exclui, para esses efeitos, qualquer um de seus órgãos ou qualquer uma de suas funções, não nos parecendo válido, pois, que a tarefa de excepcionar a regra geral encontre parâmetros legítimos na própria Constituição ou depare com alicerce sólido de construção doutrinária de qualquer espécie.

\section{A responsabilidade extracontratual do Estado no direito estrangeiro}

Em razão do que se pode extrair do restou fundamentado no articulado que compõe o desenvolvimento do presente, a teoria geral da responsabilidade do Estado é comum ao arcabouço jurídico de todas as nações que adotaram o Estado de Direito como modelo de sua organização. Do tronco comum do instituto, conforme o incremento observado em sua construção de base privatística, formou-se a concepção da responsabilidade pública, que tem norte uniforme e poucas discrepâncias conceituais nos ordenamentos jurídicos da maioria dos países. Aliás, no corpo deste trabalho se encontram inúmeras referências ao direito estrangeiro em razão da contribuição que o direito dos povos promoveu para que fosse erigido o arquétipo da teoria geral da responsabilidade de base publicista.

Entretanto, ao se tomar a comparação como instrumento para o cotejo do tratamento jurídico dispensado à responsabilidade pública, encontramos situações que, se são unidas em suas bases, diferem quanto a abordagem e ao avanço conceitual da tese que lhes serviu de referência.

Destarte, ainda que abreviadamente, é de se observar as nuances que diferem o instituto de alguns ordenamentos alienígenas, para ao final se concluir com síntese científica.

108 DI PIETRO, Maria Sylvia Zanella. Op. cit., p. 535. 


\subsection{O direito francês}

Já faz muito tempo, Duguit ${ }^{109}$ proferiu célebre frase, realçando a construção que na França se observou ao instituto da responsabilidade do Estado. O emérito Professor da Universidade de Bordeaux celebrava o grau de progresso que "honra$v a$ " seu país, seus juristas e seus tribunais na empreitada a que se fez referência.

De fato, Duguit tinha razão em fazê-lo. Isto porque, a doutrina e a jurisprudência francesas reafirmaram os mais importantes princípios da responsabilidade pública, de modo a, verdadeiramente, arquitetarem os sólidos alicerces sobre os quais hoje ainda repousam o ideário que dá os contornos do instituo.

Sem embargo, outrossim, da sólida doutrina formada acerca do assunto, é fato, entretanto, que foi a jurisprudência quem deu o incremento ao desenvolvimento das bases da responsabilidade pública estatal. Constitui-se marco paradigmático desta afirmação o julgamento, pelo Tribunal de Conflitos, do chamado Caso Blanco. precedente mais importante a servir de embrião da teoria hoje aceita e reconhecida da responsabilidade extracontratual do Estado regida por regras próprias, que, inclusive, sepultou a esquiva de não responsabilidade estatal pelos chamados atos de império.

Long, Weill e Braibant ${ }^{10}$, empreendendo estudo quanto ao célebre arrêt Blanco, explicitam que, em 08 de fevereiro de 1.873, o Tribunal de Conflitos, ao conhecer de ação proposta pelo Senhor Blanco contra o Prefeito do Departamento de Gironde, representando o Estado, que tinha por objeto a declaração da responsabilidade civil do Estado por aplicação dos artigos 1.382, 1.383 e 1.384 do Código Civil francês, por danos resultantes de ferimentos que sua filha experimentou por fato provocado por operários empregados pela Administração de Tabacos, decidiu, sob a relatoria do Conselheiro David, que os tribunais judiciais são radicalmente incompetentes para conhecer de todas as demandas propostas contra a Administração em razão de serviços públicos, qualquer que seja o objeto. Por força do restou decidido no acórdão em referência, o serviço público continua até os dias atuais como o critério para a fixação da competência administrativa.

Mas o Conselheiro David, ao relatar o acórdão, foi mais longe do que meramente fixar a competência dos tribunais administrativos em razão da matéria, ou mesmo apontar as bases da responsabilidade regida pelo direito público. De fato. "no que concerne ao fundo de direito, o arrêt Blanco vai além da questão da responsabilidade do Estado: suas considerações valem para o direito administrativo em seu conjunto. De uma parte afastou os princípios do Código Civil e de outra afirmou as características especiais das regras aplicáveis aos serviços públicos (...) as características especiais das regras aplicáveis aos serviços públicos comportam elas mesmas dois aspectos: uma concerne à autonomia do direito administrativo, no que toca não

109 DUGUIT, León. Traitè de Droit Constitutionnel. Paris. Ancienne Fontemoing, 1.930, t. III p. 460.

110 LONG, M.; WEIL, P.: BRAIBANT, Fuy. Les Grands Arrêts de la Jurisprudence Administratif. Paris, Dalloz, 1.996, pp. 02-07. 
somente ao fato de que derroga o direito civil, mas ao de que constitui um sistema próprio, com sua lógica e suas soluções" 111.

Os autores em epígrafe lembram, no entanto, que a ligação entre competência e fundo de direito não é absoluta, posto que o legislador pode modificar as regras aplicáveis aos litígios assim como pode fazer em relação à competência.

A despeito de no início haver controvérsias sentidas quanto à competência para julgar casos de responsabilidade do Estado, com o advento do julgamento do arrêt Fleuri, no ano de 1.908, a celeuma parece ter encontrado epílogo, eis que o Tribunal de Conflitos decidiu que ações dirigidas contra agentes da Administração e órgãos do Estado deveriam ser levadas à jurisdição administrativa, cabendo, a partir de então, ao Conselho de Estado a elaboração de todo um sistema de regras de responsabilidade administrativas próprias e apartadas daquelas observadas no âmbito civil, que informaram grande parte das doutrinas e regramentos positivos recepcionados posteriormente pelos demais países ocidentais de base romanística.

Após a afirmação do princípio da acumulação de responsabilidades entre agente e Poder Público observa-se um incremento no desenvolvimento da responsabilidade pública. As duas responsabilidades - pessoal do agente e da pessoa pública - não se excluem, coisa que restou solidificada a partir do que restou decidido pelo arrêt Anguet, de 1.911. Referida evolução, aliás, restou debatida anteriormente, razão de que, para evitar transformar o estudo presente num exercício enfadonho, recorre-se à possibilidade de remessa à transcrição do que restou expendido à oportunidade ${ }^{112}$.

$\mathrm{Na}$ França, hodiernamente, a Administração tem direito de regresso em relação ao culpado por falta pessoal, instituto consagrado a partir do enunciado dos julgados colacionados e decorrente do sistema de acumulação de responsabilidades. Segundo se observa da análise da evolução do entendimento do Conselho de Estado, há integração da teoria da falta do serviço com as faltas cometidas pelos agentes, exigindo-se para a consagração da responsabilidade estatal a comprovação de culpa simples, salvo raras em questões específicas, onde se exige a ocorrência de culpa grave.

Também importante observar que os franceses consagraram não só a responsabilidade por fatos da Administração, como também a decorrente do exercício da jurisdição e aquela que se afirma em razão de atos legislativos. Ao menos, é isto que se conclui a partir da doutrina de Jacqueline Morand Deviller, que esclarece que " a evolução da responsabilidade sem falta permitiu a admissão da responsabilidade do fato decorrente das leis, as quais são a expressão da soberania nacional $e$ tradicionalmente insuscetiveis de engajar a responsabilidade do Estado. Essa responsabilidade não é reconhecida, a não ser muito excepcionalmente. A condição de especialidade é raramente cumprida, sendo próprio da lei dispor da maneira mais geral possivel, sendo exigida mais uma condição: aquela presa à vontade do legislador cujo entendimento deve ter sido não excluir a reparação" 113 .

11 LONG, M.; WEIL, P.: BRAIBANT, Fuy. Op. cit., pn. 02-07.

112 C. f., pp. 17-19, deste.

113 MORAND DEVILLER. Jacqueline. Op. cit., p. 762-763. 
Segundo a autora em testilha. três são os acórdãos paradigmáticos do Conselho de Estado que sustentam esta situação: arrêt Sté des Produits Laitiers la Fleurette, de 14 de janeiro de 1.938, arrêt Caucheteux et Desmonts, de 21 de janeiro de 1.944 e arrêt Bovero, de 25 de janeiro de 1.963. Também é reconhecida, em razão desta matéria, a responsabilidade de fato decorrente das convenções internacionais. Ela é ainda mais recente e de aplicação completamente limitada, mas foi admitida pela primeira vez pelo arrêt Compagnie Générale d'Énergie Radio-Électrique, de $30 \mathrm{de}$ março de 1.966, para reparar o dano (privação de indenização) da sociedade de exploração Poste Parisien requisitada pelos alemães em 1.940, em razão de dano causado pela intervenção de convenções internacionais, transferindo para mais tarde, o exame dos créditos. Referida decisão foi confirmada posteriormente pelo arrêt Dame Burgat, de 29 de outubro de 1.976, quando se afirmou a responsabilidade estatal em razão da impossibilidade de um proprietário expulsar uma locatária esposa de um representante estrangeiro da Unesco - protegido pelo acordo de domicílio entre essa organização e a França.

No que concerne à responsabilidade de fato decorrente dos regulamentos legais, as hipóteses são, raras. A mais conhecida é que consubstancia o arrêt Commune de Gavarnie, de 22 de fevereiro de 1.963, confirmado, posteriormente, pelo arrêt Aldebert, de 13 de maio de 1.987.

Importante evolução jurisprudencial observada diz respeito ao fato que os poderes públicos estão preocupados em organizar a responsabilidade do Estado por fato da justiça judiciária. Desta forma é que foi aprovado o artigo 11 da lei de 05 de julho de 1.972. Este artigo compreende duas enunciações: 1) o Estado terá de reparar danos causados pelo funcionamento defeituoso dos serviços da justiça; 2) essa responsabilidade não é comprometida por um fato que passou dos limites ou por denegação de justiça. Ao menos é isto que nos esclarece Chapus ${ }^{14}$, que entende que "a lei parece entrar em conflito com a jurisprudência, especialmente aquela solidificada no arrêt Dr. Giry, que lavrou as possibilidades não negligenciáveis de as vítimas dos serviços de justiça, beneficiárias de regimes de responsabilidade sem falta (perfil dos colaboradores ocasionais do serviço, ou em caso de uso de armas pela polícia ou de meios perigosos) ou de responsabilidade por falta simples".

Também é reconhecida, conforme noticia o autor em epígrafe, a responsabilidade por faltas da justiça administrativa, na conformidade do que vem consignado peloo arrêt Darmont de 1.978 - esse julgado é aquele pelo qual o Conselho de Estado, pela primeira vez, determinou a responsabilidade estatal por falta da jurisdição administrativa.

\subsection{O direito italiano}

$\mathrm{Na}$ Itália, a consagração do princípio da responsabilidade extracontratual do Estado também se deu, a exemplo do que ocorre no Brasil, pelo regramento constitucional. Assim é que o artigo 28 da Constituição italiana prescreve que os servidores

114 CHAPUS, René. Droit Administratif Général. Paris, Montchrestien, 2.001, T. I, pp. 1.085-1.090. 
do Estado e dos entes públicos são diferentemente responsáveis, segundo as leis penais, civis e administrativas, pelos atos realizados com violação de direitos. Uma decisão da Corte de Cassação datada de 1.985, afirma que a responsabilidade da Administração não é meramente subsidiária, senão, assume características autônomas em relação àquela que se pode atribuir aos agentes. O direito de regresso também é previsto no direito peninsular ${ }^{115}$.

Sorace ${ }^{116}$ adverte, entretanto, que "com um único termo - responsabilidade - designa-se na linguagem jurídica italiana uma pluralidade de coisas, que permanecem mesmo quando se limita a atenção ao campo de ação da Administração Pública. Todavia, estas diversas responsabilidades terminam por ter, direta ou indiretamente, uma única referência: a pessoa a quem operam, a título diverso, constitui-se concretamente aquela que vem considerada como atividade da Administração. Qualquer uma destas diversas responsabilidades, por exigência indubitavelmente apreensivel, vem tratada em normas separadas uma da outra".

O último dos autores citados, aliás, traz à lume questão de extrema relevância, quando leciona que, para os italianos. $o$ instituto da responsabilidade civil extracontratual não pode ser constrito dentro dos limites de um modelo único. $\mathrm{O}$ modo de configurar a responsabilidade, na Itália, tanto sob o aspecto estrutural quanto sob o funcional, "é expressão de uma escolha de direito positivo entre o tanto que o legislador poderia abstratamente considerar, até o ponto que ponto que poderia sustentar".

É fato, no entanto, que a comunidade científica italiana se preocupa com algumas nuances particulares de seu direito, no que tange à responsabilidade estatal. $O$ referido artigo 28 da Constituição trouxe vários problemas interpretativos, em razão de esgotar o assunto em sua prescrição. É relevante sublinhar, entretanto, que em matéria de responsabilidade civil não existe na Itália - diferentemente de outros ordenamentos similares - e salvo em casos particulares, uma normação específica; tanto é que o citado artigo 28 remete genericamente às leis civis, de forma a consentir a "subposição aos institutos de direito comum" 117 .

Destarte, o mero reconhecimento da responsabilidade civil da Administração, desacompanhado de um adequado assento normativo da matéria, descarrega sobre o intérprete o difícil problema de adaptação da disciplina de direito comum. Todavia, para a realização deste mister, "não se de deve esquecer que a disciplina de base é data pelo Código Civil". ${ }^{118}$ Isto impõe também a verificação de quais limites são compatíveis e que possam encontrar a concreta aplicação de tais institutos, ou que limites resultarão alterados ou necessitarão de adaptação.

115 IRELLI, Vincenzo Cerulli. Corso di Diritto Amministrativo. Torino, Giappichelli, 2.000, pp. 720-738.

116 SORACE, Domenico. Le Responsabilità Pubbliche. Milão, CEDAM, 1.998, pp. XI-XIX. 117 GRECO, Guido. Diritto Amministrativo. (Coord). MAZZAROLLI, L.; PERICU, G.; ROMANO, A.; ROVERSI MONACO, F. A.; SCOCA, F. G.. Torino, Monduzzi Editore, 1.998, pp. 1.671-1.675. 118 GRECO, GUIDO. Diritto Amministrativo. (Coord). MAZZAROLLI, L.; PERICU, G.; ROMANO, A.; ROVERSI MONACO, F. A.; SCOCA, F. G.. Op. cit., pp. 1.671-1.675. 
Para complementar a teoria da responsabilidade extracontratual da Administração Pública, vale à pena assinalar, ainda que a título exemplificativo, algumas fattispecies particulares, nascidas da disciplina especial de leis ou da interpretação jurisprudencial, são destacadamente inovadoras.

No âmbito do primeiro grupo particular assume relevo a disciplina dos danos ocasionados no exercício da função jurisdicional, a qual é tratada pela lei de Lei 117 de 13 de abril de 1.988 - o ressarcimento dos danos ocasionados no exercício da função jurisdicional é responsabilidade civil dos magistrados. Tal lei também é comumente indicada como lei sobre a responsabilidade civil dos magistrados, disciplina essencialmente a responsabilidade do Estado, dado que, ao inverso, é excluída uma responsabilidade direta (contra terceiros) do magistrado singular (contra quem o Estado dispõe só de uma ação regressiva).

Independente do problema da compatibilidade de dita disciplina com o artigo 28 da Constituição se afigura cristalino que se trata de um caso de "responsabilidade direta do Estado, que por outro lado, responde somente por dolo ou culpa grave do magistrado no exercício de suas funções - ou por denegação de justiça - no sentido do artigo $3^{\circ}$ da lei" ${ }^{119}$. A ação deve ser proposta diretamente contra o Presidente do Conselho dos Ministros e pode ser exercitada somente quando foram experimentados os meios ordinários de impugnação, e submissa a um prévio juízo de admissibilidade. Como se pode constatar, se trata de uma "disciplina amplamente derrogatória daquela disciplina comum e que manifesta o esforço do legislador de adaptar com necessário temperamento o instituto do ilícito extracontratual à delicada matéria da responsabilidade do juiz, que possui à sua volta princípios e interesses públicos de relevância, como por exemplo, o de independência da magis. tratura" 120 .

Além da legislação específica que regra a responsabilidade dos magistrados, na Itália também existem outros regramentos disciplinando a responsabilidade para diferentes categorias de servidores. Controvérsias sobre reparação do dano por ação de interesse legítimo, que antes não era admitida, têm, modernamente, sido objeto revisão jurisprudencial. Hoje, grande parte da doutrina publicista mostra-se a favor da reparação em todo caso em que a Administração tenha, por ação ou omissão, causado dano a terceiros ${ }^{121}$.

\section{3. $O$ direito espanhol}

Enterría e Fernández ${ }^{122}$ sustentam que a "afirmação de um princípio geral de responsabilidade patrimonial do Estado no direito espanhol se produziu com par-

119 GRECO, GUIDO. Diritto Amministrativo. (Coord). MAZZAROLLI, L.; PERICU, G.; ROMANO, A.; ROVERSI MONACO. F. A.; SCOCA. F. G.. Op. cit.. pp. 1.671-1.675.

120 GRECO, GUIDO. Diritto Amministrativo. (Coord). MAZZAROLLI, L.; PERICU, G.: ROMANO. A.: ROVERSI MONACO, F. A.: SCOCA. F. G.. Op. cit., pp. 1.671-1.675

121 IRELLI. Vincenzo Cerulli. Op. Cit., pp. pp. XI-XIX.

122 ENTERRÍA. Eduardo García de; FERNÁNDEZ, Tomás-Ramón. Op. cit.. t. II. p. 365. 
ticular atraso" em comparação a outros países europeus. Atribuem os autores aquela situação ao fato de que ao "velho dogma de irresponsabilidade do soberano se somou a falta de vigor" da sociedade local, afogada nos desdobramentos econômicos derivada da crise que se observou da liquidação dos últimos "restos" império colonial.

Entretanto, ao longo do século XIX. pode-se detectar. em seqüência a doutrina extraída da obra dos autores em testilha. a existência de textos legais que reconhecem a responsabilidade do Estado por danos produzidos aos cidadãos, como por exemplo, a Lei de 9 de abril de 1.842 , que reconhece o direito à indenizações, como obrigação da nação, por danos materiais causados em ataques, tais como a defesa de praças, povoados e edificios, no "curso da primeira guerra carlista" 123 .

Somente em casos singulares e em virtude de texto legal expresso é que o Governo espanhol assume o dever de indenizar os danos imputáveis à seus serviços. dever aquele que, em outros casos, a contrário senso, não reconhece. também de forma expressa. como por exemplo ocorreu com a edição do Regulamento que disciplinava o Regime Interno do Corpo de Telégrafos. aprovado pela ordem ministerial de 29 de novembro de 1.900, que declarava, de forma categórica, que o Estado não aceitava responsabilidade alguma a respeito do serviço de telegrafia.

O Código Civil espanhol de 1.889. em seu artigo 1.902, veio a consagrar o princípio geral de que toda pessoa responde pelos danos que por sua ação ou omissão causar a outrem, em razão de culpa ou negligência, no que se complementou pelo disposto pelo artigo 1.903, que capitulava que a responsabilidade era exigível não só por atos e omissóes próprias, senão pelos daquelas pessoas de quem deveria responder. A combinação destes preceitos permitia, com efeito, declarar a responsabilidade do Estado por atos próprios" 124 , em razão da remissão contida no referido artigo 1.903 .

Predominou, então, a responsabilidade estatal por culpa, na conformidade do Código Civil espanhol, até que os tribunais passaram, na natural evolução da abordagem que davam ao instituto, a reconhecer, a partir do matiz privatista, a responsabilidade do Estado por "atos executados por seus empregados no desempenho de funções próprias de seus cargos", que não admitia a suposição de culpa ou negligência "na designação de seus agentes, senão, ao contrário, a previsão humanamente possivel" 125 .

As soluções jusprivatistas foram abandonadas pelo legislador espanhol com a edição da Lei de Expropriação Forçada de 16 de dezembro de 1.954. Posteriormente, a Lei do Regime Jurídico da Administração do Estado, de 26 de julho de 1.957. precisou e "matizou" a responsabilidade estatal, distinguindo a "exigivel da Administração em razão de suas atividades de direito público e de direito privado". O regime estabelecido sofreu importantes modificações, especialmente a partir da

123 ENTERRÍA. Eduardo García de; FERNÁNDEZ, Tomás-Ramón. Op. cit.. t. II. p. 366. 124 ENTERRÍA, Eduardo García de; FERNÁNDEZ, Tomás-Ramón. Op. cit., t. II. p. 366. 125 MARTíN-MATEO. Ramón. Manual de Derecho Administrativo. Madrid, Trivium Editorial. 1.999. pp. 547. 
edição da Lei de Regime Jurídico (1.957), derrogada pela Lei de Regime Jurídico das Administrações Públicas e do Procedimento Administrativo Comum, de 26 de novembro de 1.992 (modificada pela Lei 4 de 13 de janeiro de 1.999).

$\mathrm{O}$ artigo $106, \mathrm{n}^{\circ} 2$, da Constituição espanhola vigente prevê que os particulares, mos termos da lei, terão direito a ser indenizados por toda lesão em seus bens $e$ direitos, salvo os casos de força maior, sempre que a lesão seja conseqüência do funcionamento dos serviços públicos. O artigo 121, também da Constituição, consagra a reparação por erro judiciário e pelo funcionamento anormal da administração da Justiça, com indenização a cargo do Estado nos dois casos, disciplinados na Lei Orgânica do Poder Judiciário, de $1^{\circ}$ de julho de 1.985.

A reparação em geral é exigida diretamente da Administração, podendo abranger o retorno de situação anterior, se foi alterada ilegalmente. A Lei $4 / 1.999$ prevê que a anulação de atos ou disposiçōes administrativas não pressupõe direito à indenizaçã̃o ${ }^{126}$.

\section{4. $O$ direito argentino}

$D_{\text {Dromi }}{ }^{127}$ dá-nos claro panorama da evolução da teoria da responsabilidade estatal na Argentina, ao indicar a evolução jurisprudencial do instituto no país vizinho. Assim é que a Corte Suprema da Nação Argentina evoluiu do período da irresponsabilidade, cujo fundamento era "a doutrina da dupla personalidade do Estado", que se lastreava na idéia de que o Poder Público era irresponsável em virtude de sua soberania.

Num segundo momento, a Corte Suprema, modificando o critério, admitiu a responsabilidade civil do Estado, no âmbito do direito público, mas sobre bases "de culpa à ele imputável", invocando, para tanto, os artigos 1.109 e 1.113 do Código Civil. Dita evolução jurisprudencial, iniciada em idos de 1.933, resta consumada com o julgamento, em 1.942, do emblemático caso Ferrocarril Oeste de Buenos Aires contra a Província de Buenos Aires, que reconheceu a responsabilidade estatal por "danos e prejuizos emergentes de um informe errado do Registro de Propriedade". Àquela oportunidade, o Tribunal aplicou princípios de direito administrativo ao reconhecer a responsabilidade do Estado por "falta cometida no serviço" ${ }^{28}$.

No terceiro período, que "é o atual", a Corte Suprema da Nação Argentina rende-se à tese de responsabilidade estatal extracontratual lastreada em princípios eminentemente publicísticos, ao admitir a responsabilidade objetiva do Estado. Pelo posicionamento adotado, "prescinde-se que os danos derivem de comportamento ilícito, culposo ou doloso", ao se aceitar a responsabilidade sustentada na ocorrência de danos que podem derivar, tanto de situações lícitas, quanto ilícitas. A partir de então, "se abre caminho à uma concepção objetiva da antijuridicidade, colocando em relevo os elementos dano e injustiça por cima do conceito clássico de culpa" ${ }^{129}$.

126 MARTÍN-MATEO, Ramón. Op. cit., p. 550.

127 DROMI. José Roberto. Derecho Administrativo. Buenos Aires, Astrea, 1.992, pp. 278-287.

128 DROMI, José Roberto. Op. cit., p. 283.

129 DROMI, José Roberto. Op. cit., p. 284. 
Face da evolução do instituto, a Corte Suprema argentina admite a responsabilidade extracontratual do Estado, tanto no direito privado, quanto no direito público. Consagra-se, também, no país vizinho, o direito de regresso contra o funcionário ou empregado público que concorrer, com dolo ou culpa, à produção do dano.

Quanto aos atos exarados do exercício da jurisdição, a tese vigorante na jurisprudência é a da clássica solução da irresponsabilidade, com lastro na tese da incontrastabilidade da coisa julgada. Mesmo nos casos de erro judicial, a Corte Suprema da Nação Argentina nem sempre tem aceito que "exista um direito à indenização", a despeito de a doutrina ser uniforme em admiti-la, desde que se trate de erro judicial em processo penal. Quanto à responsabilidade que decorre dos atos legislativos, a jurisprudência argentina parece ser pacífica em aceitá-la quando "o prejuízo seja especial, a lei seja inconstitucional, ou o Estado se enriqueça sem causa" a partir do texto normativo ${ }^{130}$.

\section{Considerações finais}

A responsabilidade extracontratual do Estado, conforme debatido, possui tronco comum com a responsabilidade civil construída sobre dogmas privatísticos. Entretanto, a partir do reconhecimento de que o instituto é regido por regras próprias, sustentadas em bases publicistas, observa-se enorme evolução, não só dos pontos referentes à matéria específica, como também e especialmente do próprio direito público, nomeadamente na do direito administrativo, que é seu exponencial.

A assunção do modelo da responsabilidade estatal serviu de móvel ao estabelecimento de toda uma doutrina, com traços e conotações típicos, que até a presente data sustenta o direito administrativo. A partir do julgamento dos casos Blanco e Pelletier, formulou-se toda uma teoria que, além de fixar a competência administrativa, arquitetou todo o arcabouço do qual as regras e princípios de fundo do direito público, às quais o Estado tem de se submeter, não deve extravasar.

$O$ instituto da responsabilidade estatal, numa abordagem mais particularizada, continua a servir àqueles propósitos de adequação da ação estatal ao modelo de Estado de Direito, quando evolui de modo a expurgar as últimas resistências festejadoras do arbítrio, consubstanciadas na tese da irresponsabilidade, que ainda é consagrada quando o cerne da discussão é, essencialmente, a reparação de danos decorrentes do exercício da jurisdição.

Nota-se, no cotejo das experiências singulares dos ordenamentos nacionais, que pouco a pouco, entretanto, este derradeiro rincão - e verdadeiro esconderijo - da irresponsabilidade estatal vem sendo conspurcado, com a contaminação do ideário do direito dos povos pelos princípios humanitários de afirmação da justiça como base da juridicidade.

Assim é que alguns países, como França e Itália, já positivaram em normas jurídicas importantes prescrições que garantem um mínimo de proteção dos cidadãos frente ao Estado-juiz, ainda que em caos específicos.

130 DROMI, José Roberto. Op. cit., pp. 260-263. 
No Brasil, como também na Argentina, este estágio ainda não foi alcançado, ainda que na experiência pátria seja notável a evolução que a doutrina deu ao tema em comento, de modo a incrementar-lhe sobremaneira. Lamentável, apenas, que a jurisprudência brasileira não avance na mesma velocidade e ainda conserve ranços de corporativismo autoritário quando é chamada a conhecer da matéria.

Contudo, vale o registro, da comparação empreendida também se denota que o Brasil assume posição sobranceira em relação às demais nações. mesmo as européias, no que tange ao tratamento geral dispensado ao instituto. Assim é que a responsabilidade objetiva do Estado elevada ao cânone constitucional apresenta-se como pioneira.

Basta lembrar, para que a afirmação reste comprovada, que quando da edição de nossa Constituição de 1.946 - a primeira a consagrar a responsabilidade objetiva do Estado -, nos Estados Unidos e na Inglaterra ainda vigia a tese da irresponsabilidade, apoiada no princípio do the king can do no wrong.

Ainda hoje, países como a França não adotam a teoria da responsabilidade objetiva na sua integralidade. fenômeno que se repete na Itália e Espanha, ainda que a síntese da evolução da matéria aponte neste caminho, na conformidade, aliás, da célebre profética frase de Duguit ${ }^{131}$.

De fato, a teoria da responsabilidade extracontratual estatal, com bases fincadas no direito público, é fenômeno em eterna evolução (e ebulição). O Estado, cujo conceito cambiante modifica-se em face da evolução, não só do instituto que representa, mas, especialmente, em razão incrementos observados na sociedade transcendente, permite que aquela afirmação seja feita, sem margem de possibilidade ao estabelecimento de um sofisma. Destarte, cabe ao direito, e seus operadores, a redobrada atenção para a adequação dos direitos do cidadão em razão da ação e das responsabilidades que o Estado deve assumir, num modelo democrático de organização.

Do Brasil se exige. além disto, a responsabilidade adicional, que advém do pioneirismo do desenvolvimento de seu direito.

\section{Bibliografia}

ARANA MUÑOZ, Jaime Rodriguez. Nuevas Orientaciones Doctrinales sobre la Responsabilidad Patrimonial de la Administración Pública. Braga: In SCIENTIA IURIDICA, Universidade do Minho, $\mathrm{n}^{\circ}$ 293, maio/agosto, 2.002.

ARAÚJO, Edmir Netto de. Responsabilidade do Estado por Ato Jurisdicional. São Paulo: Revista dos Tribunais, 1.981.

CAHALI, Yussef Said. Responsabilidade Civil do Estado. São Paulo: Malheiros, 1.995.

CAHALI, Yussef Said (Coord.). Responsabilidade Civil. São Paulo, Saraiva, 1.988.

131 C. f., p. 18, deste. 
CANOTILHO, José Joaquim Gomes. Direito Constitucional. Coimbra: Almedina, 1.992.

CHAPUS, René. Droit Administratif General. Paris: Montchrestian, 2.001.

CRETELLA JUNIOR, José. Tratado de Direito Administrativo. Rio de Janeiro: Forense, 1966/1972.

Direito Administrativo Brasileiro. Rio de Janeiro: Forense, 1.983.

Manual de Direito Administrativo. Rio de Janeiro: Forense, 1.989.

DEVOLVÉ, Pierre; VEDEL, Georges. Droit Administratif. Paris: Presses Universitaires de France: 1.980.

DIAS, José de Aguiar. Da Responsabilidade Civil. Rio de Janeiro: Forense, 1.987.

DI PIETRO, Maria Sylvia Zanella. Direito Administrativo. São Paulo: Atlas, 2.003. Do Direito Privado na Administração Pública. São Paulo: Atlas. 1.989.

Discricionariedade Administrativa na Constituição de 1988. São Paulo: Atlas, 1991.

DUGUIT, Léon. Manuel de Droit Constitutionnel. Paris: Fontemoing et Cie. Editeurs, 1911.

DROMI, José Roberto. Derecho Administrativo. Buenos Aires: Astrea, 1.991.

EINSENMANN, Charles. Cours de Droit Administratif. Paris: LGDF, 1.982.

ENTERRÍA, Eduardo García de: FERNÁNDEZ, Tomás-Ramón. Curso de Derecho Administrativo. Madrid: Editorial Civitas, 1.998.

FERRAZ JÚNIOR. Tercio Sampaio. Introdução ao Estudo do Direito - Técnica, Decisão, Dominação. São Paulo: Atlas, 2.003.

FERNÁNDEZ, Tomás-Ramón; ENTERRÍA. Eduardo García de. Curso de Derecho Administrativo. Madrid: Editorial Civitas, 1.998.

FIGUEIREDO, Lúcia Valle. Curso de Direito Administrativo. São Paulo: Malheiros, 1999.

FRAGA, Gabino. Derecho Administrativo. México: Editorial Porruá, 1.979.

GASPARINI, Diogenes. Direito Administrativo: São Paulo: Saraiva, 2.003.

GIANNINI, Massimo Severo. Diritto Amministrativo. Milano: Dott A. Giuffré, 1.970.

GORDILLO, Agustín A. Princípios Gerais de Direito Público. São Paulo: RT, 1977. Tratado de Derecho Administrativo. Buenos Aires: Macchi-López, 1975.

La Administración Paralela. Madrid: Civitas, 1982.

GRECO, Guido. Diritto Amministrativo. (Coord). MAZZAROLLI, L.; PERICU. G.; ROMANO, A.; ROVERSI MONACO, F. A.; SCOCA, F. G.. Torino: Monduzzi Editore, 1.998.

HAURIOU, Maurice. Précis de Droit Administratif et Droit Public. Paris: Recueil Sirey, 1.911.

IRELLI, Vincenzo Cerulli. Corso di Diritto Amministrativo. Torino: Giappichelli, 2.000 .

JELLINEK, Georg. Teoria General Del Estado. México: Editora Continental S/A, 1.956.

KELSEN, Hans. Teoria Geral do Direito e do Estado. São Paulo: Martins Fontes, 1.995.

LONG, M.; WEIL, P.; BRAIBANT, Fuy. Les Grands Arrêts de la Jurisprudence Administratif. Paris: Dalloz, 1.996. 
MARIENHOFF, Miguel S. Tratado de Derecho Administrativo. Buenos Aires: Abeledo-Perrot. 1.997.

MARKY, Tomas. Curso Elementar de Direito Romano. São Paulo: Saraiva, 1.995. MARTÍN-MATEO, Ramón. Manual de Derecho Administrativo. Madrid: Trivium, 1.999.

MAYER, Otto. Derecho Administrativo Alemán. Buenos Aires: Depalma, 1949.

MEDAUAR, Odete. Direito Administrativo Moderno. São Paulo: RT, 2.003. Direito Administrativo em Evolução. São Paulo: RT, 1.992. A Processualidade no Direito Administrativo. São Paulo: RT. 1.993. Atos de Governo. Revista de Direito Administrativo. Rio de Janeiro: Editora Renovar, 1.993 (jan./mar.).

MEIRELLES, Hely Lopes. Direito Administrativo Brasileiro. São Paulo: RT, 1.989. MELLO, Celso Antonio Bandeira de. Curso de Direito Administrativo. São Paulo: Malheiros, 2.003.

MELLO, Oswaldo Aranha Bandeira de. Princípios Gerais de Direito Administrativo. Rio de Janeiro: Forense, 1969/1974. 2 v.

MERKL, Adolf. Teoria General deI Derecho Administrativo. México: Editora Nacional. 1980.

MORAND-DEVILLER. Jacqueline. Cours de Droit Administratif. Paris: Montchréstien, 2001.

MOREIRA ALVES, José Carlos. Direito Romano. Rio de Janeiro: Forense. 2.001.

MORTATI, Costantino. Instituzioni di Diritto Pubblico. Padova: Cedam - Casa Editrice Dott. Antonio Milani, 1.975.

PAILLET, Michel. La Responsabilité Administratif. Paris: Dalloz, 1.996.

RIVERO, Jean. Direito Administrativo. Coimbra: Almedina, 1981.

ROLLAND, Louis. Précis de Droit Administratif: Paris, Dalloz, 1.947.

SANTOS NETO, João. Responsabilidade Civil do Estado por atos Judiciais e Jurisdicionais. In Boletim de Direito Administrativo. São Paulo: Editora N.D.J., $\mathbf{n}^{\circ}$ $1,2.002$.

SILVA, José Afonso da. Curso de Direito Constitucional Positivo. São Paulo Malheiros, 2.001.

SILVA, Juary C.. A Responsabilidade do Estado por Atos Judiciários e Legislativos. São Paulo: Saraiva, 1.985.

SORACE, Domenico. Le Responsabilità Pubbliche. Milão: CEDAM, 1.998.

VEDEL, Georges; DEVOLVÉ, Pierre. Droit Administratif. Paris: Presses Universitaires de France, 1980.

VILLATA, Ricardo. Diritto Amministrativo. Bolonha: Obra Colletiva, 1998.

ZANOBINI. Guido. Corso di Diritto Amministrativo. Milano: A. Giuffrè, 1968. 